\title{
Distribution and Geochemical Controls of Arsenic and Uranium in Groundwater-Derived Drinking Water in Bihar, India
}

\author{
Laura A. Richards 1,*(D), Arun Kumar ${ }^{2} \mathbb{D}$, Prabhat Shankar ${ }^{2}$, Aman Gaurav ${ }^{2}$, Ashok Ghosh ${ }^{2}$ and \\ David A. Polya ${ }^{1}$ \\ 1 Department of Earth and Environmental Sciences and Williamson Research Centre for Molecular \\ Environmental Science, The University of Manchester, Williamson Building, Oxford Road, \\ Manchester M13 9PL, UK; david.polya@manchester.ac.uk \\ 2 Mahavir Cancer Sansthan and Research Center, Phulwarisharif, Patna 801505, India; \\ arunk31@gmail.com (A.K.); prabhataryapat@gmail.com (P.S.); gauravaman2@gmail.com (A.G.); \\ ashok.ghosh51@gmail.com (A.G.) \\ * Correspondence: laura.richards@manchester.ac.uk
}

Received: 12 March 2020; Accepted: 2 April 2020; Published: 6 April 2020

\begin{abstract}
Chronic exposure to groundwater containing elevated concentrations of geogenic contaminants such as arsenic (As) and uranium (U) can lead to detrimental health impacts. In this study, we have undertaken a groundwater survey of representative sites across all districts of the State of Bihar, in the Middle Gangetic Plain of north-eastern India. The aim is to characterize the inorganic major and trace element aqueous geochemistry in groundwater sources widely used for drinking in Bihar, with a particular focus on the spatial distribution and associated geochemical controls on groundwater As and $U$. Concentrations of As and $U$ are highly heterogeneous across Bihar, exceeding (provisional) guideline values in $\sim 16 \%$ and $7 \%$ of samples $(n=273)$, respectively. The strongly inverse correlation between As and $U$ is consistent with the contrasting redox controls on As and U mobility. High As is associated with $\mathrm{Fe}, \mathrm{Mn}$, lower Eh and is depth-dependent; in contrast, high $\mathrm{U}$ is associated with $\mathrm{HCO}_{3}{ }^{-}, \mathrm{NO}_{3}{ }^{-}$and higher Eh. The improved understanding of the distribution and geochemical controls on As and $U$ in Bihar has important implications on remediation priorities and selection, and may contribute to informing further monitoring and/or representative characterization efforts in Bihar and elsewhere in India.
\end{abstract}

Keywords: arsenic; uranium; Bihar; India; groundwater quality; groundwater monitoring

\section{Introduction}

Elevated concentrations of naturally occurring As and $U$ in groundwater present a major environmental and public health challenge globally. Groundwaters within the major floodplains and deltas in South/Southeast (S/SE) Asia, as well as elsewhere across the world, can naturally contain dangerous concentrations of As [1-5] exceeding the World Health Organization (WHO) provisional guideline value of $0.13 \mu \mathrm{M}\left(10 \mu \mathrm{g} . \mathrm{L}^{-1}\right)$ [4]. In S/SE Asia, As impacts the health of millions of people and has been well documented in areas of Bangladesh [5-15], Cambodia [16-29], Vietnam [30-41], Pakistan [42-45] and more recently, Myanmar [46-49]. In India, groundwater As, particularly in the Ganga Basin, has been widely reported in West Bengal [50-70] (noting that a reduced As hazard as compared with previous estimates has recently been postulated in a Kolkata-based study [71]), Uttar Pradesh [72-75] and Bihar [76-83]. In Bihar specifically, As was first reported in 2003 in Bhojpur district [76]. In 2007, a largescale study of $\sim 67,000$ water sources reported elevated As in 11 districts of Bihar (Begusarai, Bhagalpur, Bhojpur, Buxar, Katihar, Khagaria, Munger, Patna, Samastipur, Saran and 
Vaishali, noting importantly that only sources within $10 \mathrm{~km}$ of the Ganga River were sampled) [77]. Most recently, it has been reported that 22 districts of Bihar are currently As-impacted, although no further details such as location, non-summarized data or the functional definition of "As-impacted" are included [78]. Further, wheat consumption has recently been identified as an emerging route of As exposure in Bihar [84]. Although thorough reviews of the status of As in the Gangetic Basin are published elsewhere [78,85], the estimated population at risk for As contamination in West Bengal is 26 million people, followed by Bihar (9 million), Uttar Pradesh ( 3 million), Assam (1.2 million), Manipur (1 million) and Jharkhand (0.4 million) [85].

Widespread in nature, $U$ is a radionuclide which geogenically occurs in granite and other rock types. $\mathrm{U}$ in groundwater can occur due to natural mobilization processes under oxic conditions, and can also be associated with anthropogenic activities such as mining, coal and fuel combustion, emissions from the nuclear industry and the use of $\mathrm{PO}_{4}$-based fertilizers containing $\mathrm{U}$ [4]. As chronic exposure to $\mathrm{U}$ may lead to numerous adverse health impacts including bone toxicity and impaired renal function [86,87], WHO has set a provisional guideline value of $0.13 \mu \mathrm{M}\left(30 \mu \mathrm{g} \cdot \mathrm{L}^{-1}\right)$, noting that Germany adopted a lower threshold of $0.04 \mu \mathrm{M}\left(10 \mu \mathrm{g} \cdot \mathrm{L}^{-1}\right)$ in 2011 [88]. Elevated concentrations of $U$ in groundwater have been identified across the globe, including in North America (e.g., Canada [89], the United States [90,91]), Europe (e.g., Finland [87], Sweden [92], Switzerland [93], the United Kingdom [94]) and Asia (e.g., Bangladesh [95], China [96,97], Korea [98], Mongolia [99], Pakistan [43] and in the lower Mekong delta [100]), noting this is a non-exclusive list. In the Indian context specifically, U has been reported in groundwater in the States of Andhra Pradesh [101], Bihar [102-104], Chhattisgarh [105], Haryana [106], Jammu \& Kashmir [107], Jharkhand [108-110], Himachal Pradesh [111], Karnataka [112], Kerala [113], Punjab [114], Rajasthan [115], Uttar Pradesh [116] and West Bengal [70]. A partial review of the range of $U$ concentrations encountered in various Indian states is included in [102,105]. In Bihar, to the authors' knowledge, published $\mathrm{U}$ studies are sparse and have been limited to five southwestern districts of Auranagabad, Gaya, Jahenabad, Nalada and Nawada where U was reported in elevated concentrations in selected samples [102,104], ranging in concentration from 0.1 to $\sim 240 \mu \mathrm{g}$. $\mathrm{L}^{-1}$ $(\sim 0.0004$ to $\sim 1 \mu \mathrm{M})$ [102], and in several blocks of Patna where $U$ was below permissible limits [103]. The co-occurrence of groundwater As and $U$ has recently been reported in the neighbouring state of Uttar Pradesh [117].

The mobility and fate of both As and $U$ in groundwater are highly dependent on local redox conditions. For As, mobilization in shallow, reducing groundwaters typical to S/SE Asia is generally attributed to reductive dissolution of As-bearing Fe(III) minerals $[1,118]$ via metal-reducing bacteria and labile organic matter [2,32,118-121]. Mechanistic questions regarding the nature of organic matter $[6,15,23,25,26,61,121-129]$ and where in the subsurface As mobilization occurs $[6,25,26,130-134]$ remain important in developing predictions of future changes in As hazard [6,24,26]. Additional competing processes such as adsorption/desorption [135-137] and co-precipitation [138] can also impact As mobility. Similarly to As, redox conditions are a major control on the mobilization and fate of $U$. The dominant species of $U$ in aqueous solutions with oxic to suboxic conditions are the highly mobile U(VI) species [139], whereas the reduced species of U(IV) are relatively immobile [140]. Further processes, such as sorption/desorption, precipitation/dissolution and complexation with carbonates [88,141,142], humic acids [143] and other organics [144] can impact $\mathrm{U}$ mobility in groundwater.

Published groundwater studies particularly for Bihar remain relatively limited as compared with the neighbouring states in the Gangetic Basin of India. The lack of availability of systematic and representative (non-summarized) data in the public domain remains a major limitation to enable understanding of geochemical controls, prediction of future changes or developing effective monitoring and/or mitigation schemes. As such, the aim of this study is to systematically obtain, evaluate and interpret representative primary groundwater (inorganic) chemical quality data for Bihar, India, in order to (i) understand the distribution of geogenic groundwater contaminants, notably As and $\mathrm{U}$, across Bihar; and to (ii) characterise the dominant geochemical conditions and processes likely to 
impact groundwater geochemistry in Bihar. This manuscript builds upon preliminary results initially presented by Richards et al. [145].

\section{Materials and Methods}

\subsection{Field Area Description}

The study region is in the north-eastern state of Bihar, India, in the Middle Gangetic Plain and with a land area of $\sim 94,000 \mathrm{~km}^{2}$ (Figure 1) [145]. Field sites were targeted in advance to encompass (i) representative sampling across all 38 districts of Bihar; (ii) minimized bias in sample selection; and (iii) logistic feasibility such as road access. The timing of samples was coordinated to avoid local election schedules for reasons of greater efficiency and safety. At least two (and ideally three) sampling depths were targeted at every site; in most cases, two depths were identified with local advice and usually were found easily within $\sim 500 \mathrm{~m}$ of each target location. Depths were selected to capture the typical range of depths of groundwater wells used for drinking water in a particular area, and ranged from $\sim 5$ to $180 \mathrm{~m}$ depending on site. Higher-resolution sampling was undertaken in Patna district ( $n=62$; see Section 3.2 for detailed discussion) due to ongoing research in this area. With the total number of samples $(n=273)$ and an average of two depths collected per site, the approximate sampling density was two sites (of varying depths) per $\sim 680 \mathrm{~km}^{2}$. Bihar is mostly dominated by recent Quaternary deposits and, in the south, much older pre-Cambrian features; further hydrogeological characterization of Bihar is reported elsewhere $[81,82]$.

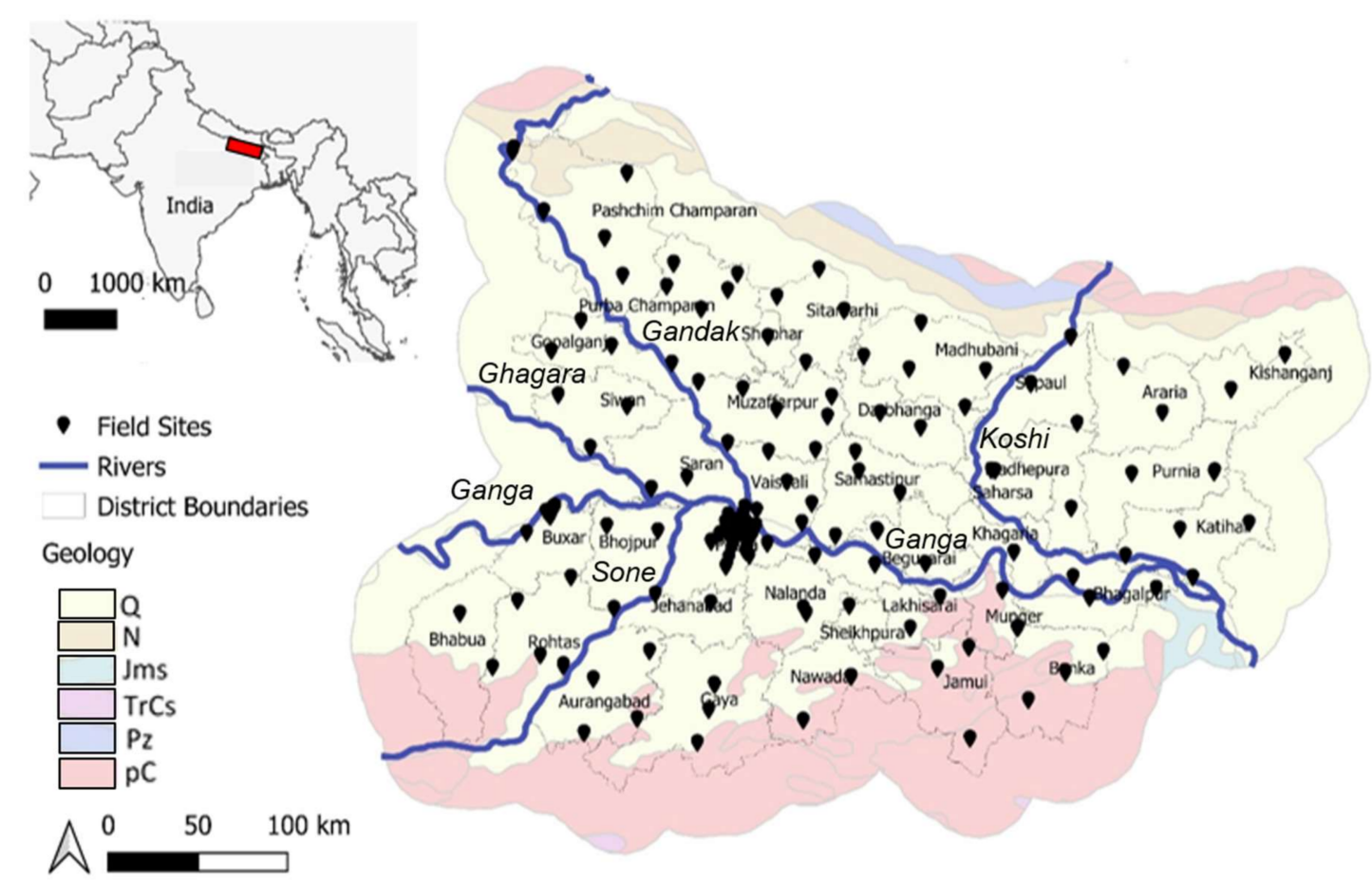

Figure 1. Groundwater sampling sites in Bihar, India [145] with major rivers labelled. Open-access layers are from Natural Earth [146], and geological layers from the US Department of Interior [147]. Geochronological categorization: $\mathrm{Q}=$ Quaternary; $\mathrm{N}=$ Neocene; Jms = Jurassic; $\operatorname{TrCs}=$ Triassic carboniferous; $\mathrm{Pz}=$ Paleozoic; $\mathrm{pC}=$ Pre-Cambrian. Area of detailed site map corresponds approximately to red box on regional map.

\subsection{Water Sample Collection}

Water sampling $(n=273)$ was conducted predominately in early and mid-2019 in the pre-monsoon season in Bihar, with the inclusion of a few additional samples collected in November $2018(n=3)$ and December $2019(n=4)$. Groundwater (from a depth range of approximately 5 to $180 \mathrm{~m}$ ) was collected 
from existing private and government wells, either connected to a manual hand pump or on occasion an electrical submersible pump depending on the site. All sampled wells were in regular use and were pumped for at least $1-2$ minutes prior to collecting samples.

The subset of four samples from December 2019 were non-random samples collected from a known high-As area in Samastipur, an area of ongoing research by co-authors at Mahavir Cancer Sansthan for the purposes of external data verification; the results related to these samples are included for As only.

Subsamples of groundwater for cation, anion and dissolved organic carbon (DOC) analyses were immediately filtered $(0.45 \mu \mathrm{m}$ cellulose/polypropylene syringe filters, Minisart RC, Fisher Scientific, UK) upon collection, using similar methods as previously described [27]. Due to transport restrictions regarding nitric acid, subsamples for cation and trace metal(loid) analysis were acidified upon arrival at University of Manchester within the Manchester Analytical Geochemistry Unit (MAGU) laboratories using $2 \%$ trace analysis-grade nitric acid distilled in-house. All samples were stored in bottles which had been prepared in advance by acid wash ( $10 \%$ nitric acid wash) followed by thorough rinsing with deionized water (MilliQ grade) and furnacing at $400{ }^{\circ} \mathrm{C}$ to remove trace contamination.

\subsection{Aqueous Analytical Measurements}

Measurements on aqueous samples were conducted in both field and laboratory settings [27]. Field measurements included $\mathrm{pH}$, oxidation-reduction potential $(E h)$, temperature and electrical conductivity, collected in-situ using Hanna handheld meters. Cations were analysed using inductively coupled plasma atomic emission spectrometer (ICP-AES, Perkin-Elmer Optima 5300 dual view; for analysis of $\mathrm{Ca}, \mathrm{Mg}, \mathrm{Na}, \mathrm{K}, \mathrm{Si}, \mathrm{Fe}, \mathrm{Mn}$ and $\mathrm{P}$ ) and/or inductively coupled plasma mass spectrometry (ICP-MS, Agilent 7500cx; for analysis of As, $\mathrm{U}, \mathrm{Cu}, \mathrm{Zn}$ and $\mathrm{Pb}$ ), both located within MAGU at The University of Manchester [27]. Anions were analysed using ion chromatography (IC; Dionex ICS5000 Dual Channel Ion Chromatograph; for analysis of $\mathrm{F}^{-}, \mathrm{Cl}^{-}, \mathrm{NO}_{3}{ }^{-}, \mathrm{NO}_{2}{ }^{-}, \mathrm{SO}_{4}{ }^{2-}$ and $\left.\mathrm{Br}^{-}\right)$at MAGU. The method detection limit (also shown on Table 1) was $0.01 \mathrm{mg} . \mathrm{L}^{-1}$ for ICP-AES (corresponding to $0.0002 \mathrm{mM}$ for $\mathrm{Ca}$, Fe and $\mathrm{Mn}$; $0.0003 \mathrm{mM}$ for $\mathrm{K}$ and P; and $0.0004 \mathrm{mM}$ for $\mathrm{Mg}$, Na and Si) and $1 \mu \mathrm{g} . \mathrm{L}^{-1}$ for ICP-MS (corresponding to $0.01 \mu \mathrm{M}$ for As; $0.02 \mu \mathrm{M}$ for $\mathrm{Cu}$ and $\mathrm{Zn} ; 0.004 \mu \mathrm{M}$ for $\mathrm{U}$; and $0.005 \mu \mathrm{M}$ for $\mathrm{Pb}$ ). For IC, the method detection limit was $0.1 \mathrm{mg} \cdot \mathrm{L}^{-1}$ for $\mathrm{Br}^{-}$and $\mathrm{NO}_{2}{ }^{-}(0.001$ and $0.002 \mathrm{mM}$, respectively), $0.05 \mathrm{mg} . \mathrm{L}^{-1}$ for $\mathrm{F}^{-}(0.003 \mathrm{mM})$ and $0.2 \mathrm{mg} . \mathrm{L}^{-1}$ for $\mathrm{Cl}^{-}, \mathrm{SO}_{4}{ }^{2-}$ and $\mathrm{NO}_{3}{ }^{-}(0.006,0.002$ and $0.003 \mathrm{mM}$, respectively). Alkalinity was estimated by charge balance (e.g., the charge balance as calculated with measured concentrations of major cations, and measured concentrations of major anions including estimated alkalinity, was assumed to be zero); this parameter was not determined analytically during this study.

\subsection{Quality Assurance and Quality Control}

The quality assurance/quality control $(\mathrm{QA} / \mathrm{QC})$ measures undertaken during sampling and analyses were similar to as described in our previous work [27,148,149]. Method comparisons were undertaken to compare the impact of the simplified sampling strategy employed here (e.g., no acidification at the time of sampling) via comparison of in-lab filtration and acidification. Certified reference materials (CRMs) included SPS-SW1 (LGC Standards, Middlesex, UK), SRM 1640a (National Institute of Standards and Technology, USA), TM-25.5 (National Water Research Institute, Environment Canada) and CA011C (European Reference Material, LGC Standards, Middlesex, UK) for ICP-MS and ICP-AES, and LGC6020 (LGC Standards, Middlesex, UK) for IC. Duplicate analysis was conducted on $15 \%$ of the samples, and seven-point calibrations were repeated every 10 samples. Inverse variance weighted first order linear models were used for ICP-AES and ICP-MS calibration outputs [148,149]. 


\subsection{Statistical Analysis and GIS}

All statistical analysis was conducted using OriginPro 2017 and Microsoft Excel, and regression statistics are reported at $95 \%$ confidence as " $t$ (degrees of freedom $)=t$ value; $p=p$ value". Analyses of water samples with concentrations below method detection limits (as listed on Table 1) were treated as (i) zero in tabulated statistical calculations for quartiles, median and mean and (ii) as the method detection limit for correlation/regression calculations. In some Figures, including box plots, samples with measured concentrations below detection limit are included at the maximum feasible concentration (e.g., the method detection limit) to avoid bias or misinterpretation of data introduced by non-inclusion of below-detection samples; see figure captions for details. Maps were created using open-source QGIS (Version 3.10 A Coruña; https://qgis.org/en/site/), with open-access layers from Natural Earth [146] and geological layers from the US Department of Interior [147].

\section{Results}

\subsection{Data Quality}

The mean calculated bias for ICP-MS analytes across analytical runs reported here (March 2019, April 2019, July 2019 and January 2020), based on CRM SPS-SW1, is as follows: $-1 \%$ for $\mathrm{Cu}, 3 \%$ for $\mathrm{Zn}$, $0 \%$ for As and $4 \%$ for $\mathrm{Pb}$. For U, bias is $-5 \%$ at $25.4 \mu \mathrm{g}$. $\mathrm{L}^{-1}$ (CRM 1640a, only available for the March 2019 and January 2020 analytical runs) and 37\% at $0.5 \mu \mathrm{g} . \mathrm{L}^{-1}$ (CRM SPS-SW1, noting the certified value is below the lowest calibration standard used of $1 \mu \mathrm{g} . \mathrm{L}^{-1}$ ). The July 2019 ICP-MS analytical run tended towards slightly higher analytical bias than the other analytical dates. For ICP-AES analytical runs in March, April and July 2019, the mean calculated bias on the basis of CRM SPS-SW1 is $0 \%$ for $\mathrm{Fe},-3 \%$ for $\mathrm{Mn},-7 \%$ for $\mathrm{P},-11 \%$ for $\mathrm{Ca},-12 \%$ for $\mathrm{Mg},-20 \%$ for $\mathrm{Na}$ and $-30 \%$ for $\mathrm{K}$. For IC analytical runs in March and August 2019, mean calculated bias on the basis of CRM LGC6020 is $-6 \%$ for $\mathrm{Cl}^{-}$, $-8 \%$ for $\mathrm{F}^{-},-1 \%$ for $\mathrm{NO}_{3}{ }^{-}$and $-3 \%$ for $\mathrm{SO}_{4}{ }^{2-}$. No corrections were made on the basis of analytical bias, particularly due to the reasonable agreement observed for the parameters of primary interest. Methodological comparisons of filtration only in the field versus acidification (for a minimum of $48 \mathrm{~h}$ ) followed by filtration in the laboratory showed reasonable agreement. Duplicate analyses were typically within $\sim 10 \%$.

\subsection{Dominant Groundwater Geochemical Conditions}

The major and trace elemental composition of Bihar groundwater is summarized in Figure 2. The bulk cationic charge is dominated by $\mathrm{Na}, \mathrm{Ca}$ and $\mathrm{Mg}$ (contributing a max of $78 \%, 73 \%$ and $58 \%$, respectively), followed by $\mathrm{K}$, whereas $\mathrm{HCO}_{3}{ }^{-}$and $\mathrm{Cl}^{-}$dominate the bulk anionic charge (contributing a max of $99 \%$ and $63 \%$, respectively), followed by $\mathrm{SO}_{4}{ }^{2-}$ and $\mathrm{NO}_{3}{ }^{-}$. Traces, in broad order of decreasing concentrations, include $\mathrm{F}^{-}, \mathrm{Fe}, \mathrm{Mn}, \mathrm{P}, \mathrm{Zn}, \mathrm{As}, \mathrm{U}, \mathrm{Cu}$ and $\mathrm{Pb}$.

A Piper diagram (Figure 3) indicates the majority of the groundwater is of the $\mathrm{Ca}-\mathrm{HCO}_{3}{ }^{-}$ type, with some samples instead $\mathrm{Na}-\mathrm{HCO}_{3}{ }^{-}$type. The dominance of $\mathrm{Ca}-\mathrm{HCO}_{3}{ }^{-}$water is typical of shallow groundwater, and the samples which instead reflect $\mathrm{Na}-\mathrm{HCO}_{3}{ }^{-}$type water suggest ion exchange reactions have influenced the groundwater composition. Most groundwater samples were circum-neutral ( $\mathrm{pH}$ ranging from 5.7 to 8.3; median $=7.2$ ), with a wide range of $E$ h (ranging from $\sim 30$ to $420 \mathrm{mV}$; median $=200 \mathrm{mV})$, electrical conductivity $\left(E C\right.$; ranging from 0.03 to $3.1 \mathrm{mS}^{\circ} \mathrm{cm}^{-1}$; median $\left.=0.65 \mathrm{mS} . \mathrm{cm}^{-1}\right)$ and relatively warm groundwater temperatures $\left(\sim 22\right.$ to $36^{\circ} \mathrm{C}$; median: $\left.27^{\circ} \mathrm{C}\right)$. Concentrations of groundwater As range from $<0.01$ to $11.6 \mu \mathrm{M}\left(\sim<1\right.$ to $\left.\sim 870 \mu \mathrm{g} . \mathrm{L}^{-1}\right)$, with $\sim 16 \%$ of samples exceeding the WHO provisional guideline of $0.13 \mu \mathrm{M}\left(10 \mu \mathrm{g} . \mathrm{L}^{-1}\right)$ [4], and $\sim 4 \%$ exceeding $0.67 \mu \mathrm{M}\left(50 \mu \mathrm{g} . \mathrm{L}^{-1}\right)$. Groundwater $\mathrm{U}$ concentrations range from 0.0 to $0.35 \mu \mathrm{M}\left(\sim<1\right.$ to $\left.\sim 80 \mu \mathrm{g} . \mathrm{L}^{-1}\right)$, with $\sim 7 \%$ of samples exceeding the WHO provisional guideline of $0.13 \mu \mathrm{M}\left(30 \mu \mathrm{g} . \mathrm{L}^{-1}\right)$. Neither As nor $\mathrm{U}$ is normally distributed at the 0.05 level according to the Shapiro-Wilk normality test. Full summary statistics are provided in Table 1. 


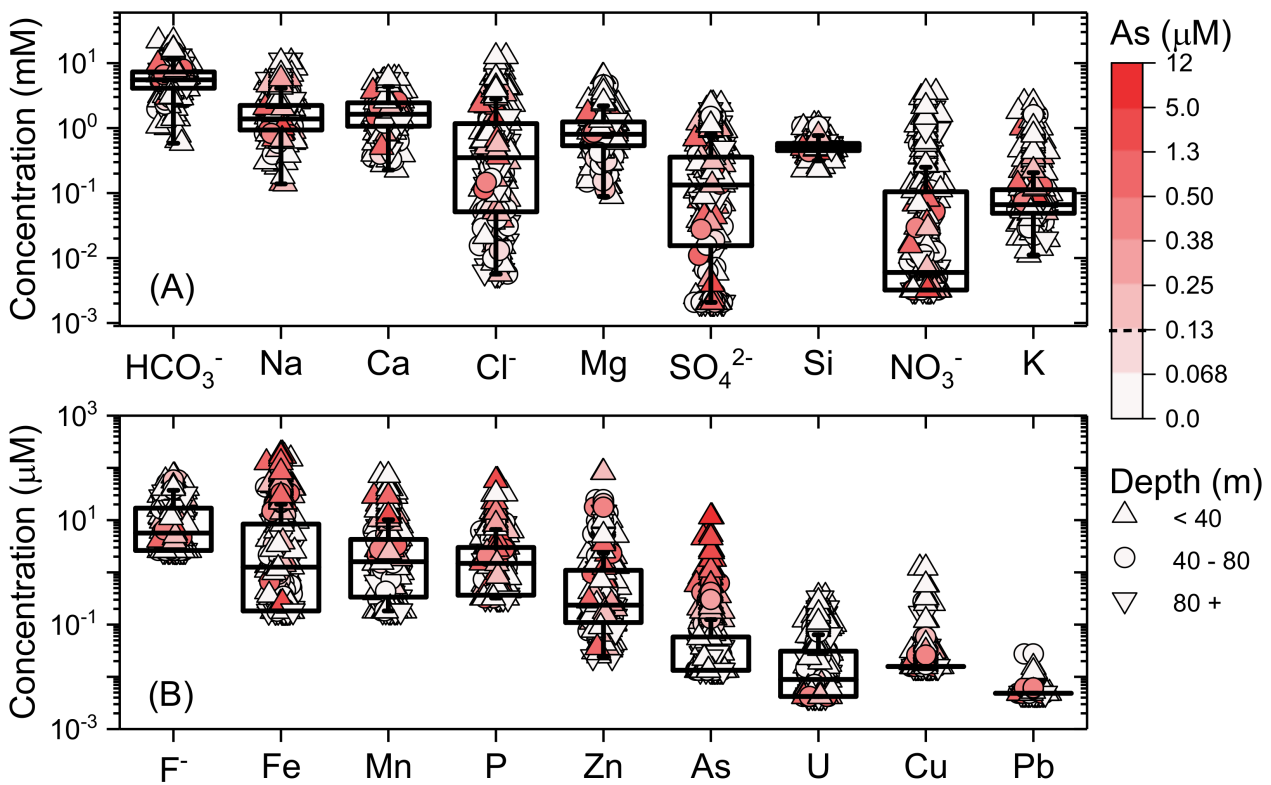

Figure 2. Box and Whisker diagram for (A) majors and (B) traces across Bihar. Boxes represent the $25-75 \%$ distribution (central line within box represents the median), and lines indicating the $5 \%$ and 95\% intervals. Colour scale indicates As concentrations, and symbol shape indicates reported depth. Samples with measured concentrations below detection for a particular analyte were calculated based on maximum concentration at method detection limit for inclusion in box plots; where median or lower whiskers are not clearly seen there are high numbers of samples below detection.

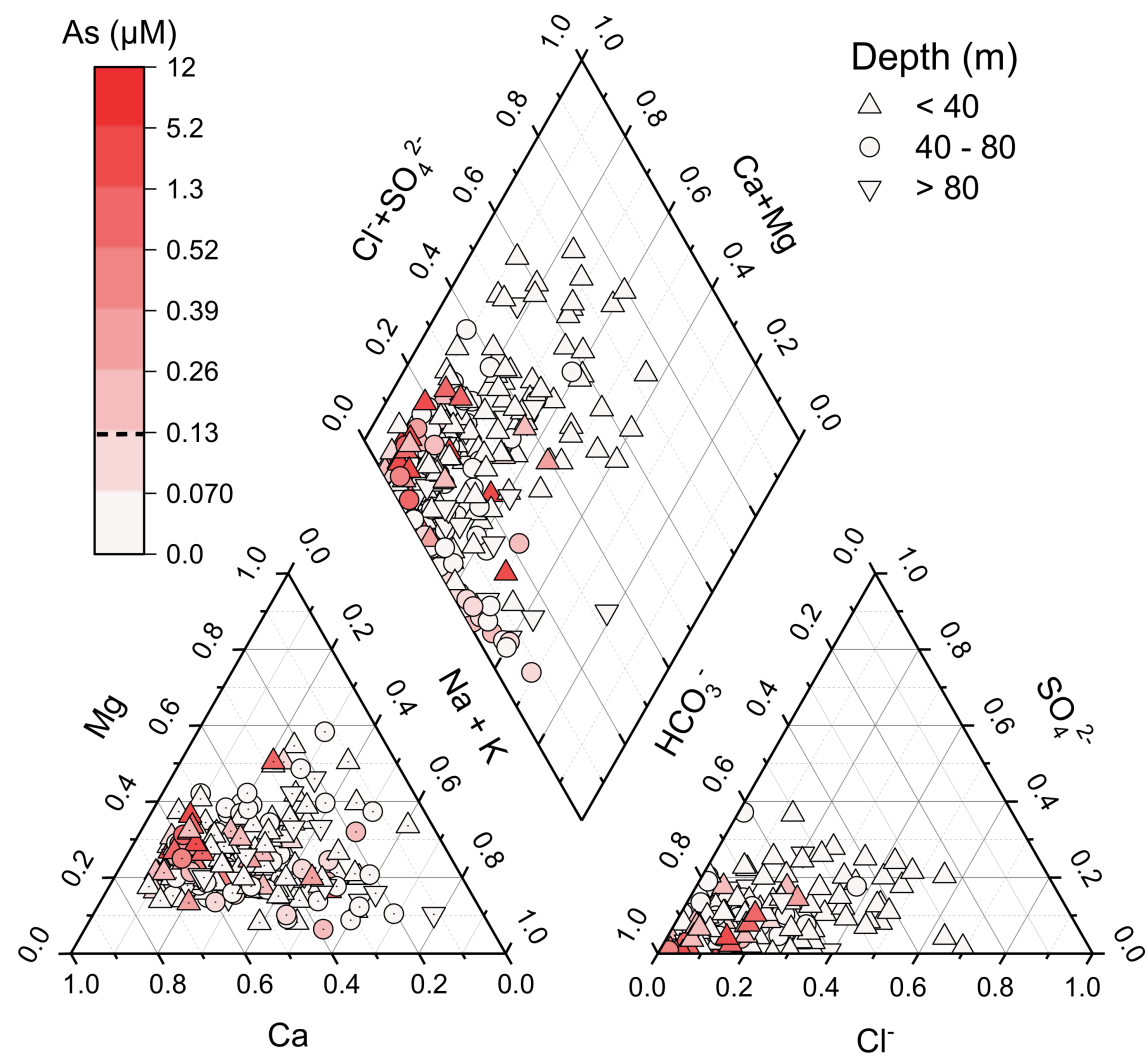

Figure 3. Piper diagram of Bihar groundwater $(n=273)$; Colour scale indicates As concentrations, and symbol shape indicates reported depth. 
Table 1. Summary statistics for geochemistry of Bihar groundwater; MDL = method detection limit; $\mathrm{Q}=$ quartile; $\mathrm{n} / \mathrm{a}=$ not applicable. Samples with measured concentrations below detection for a particular analyte are included as zero in summary statistic calculations.

\begin{tabular}{lcccccc}
\hline \multicolumn{1}{c}{ Analyte } & MDL & Min & Q1 & Median & Q3 & Max \\
\hline $\mathrm{pH}(-)$ & $\mathrm{n} / \mathrm{a}$ & 5.7 & 7.0 & 7.2 & 7.5 & 8.3 \\
$\mathrm{Eh}(\mathrm{mV})$ & $\mathrm{n} / \mathrm{a}$ & 30 & 110 & 200 & 240 & 420 \\
Elec. Cond. $\left({\left.\mathrm{mS} . \mathrm{cm}^{-1}\right)}^{\mathrm{n}}\right.$ & $\mathrm{n} / \mathrm{a}$ & 0.03 & 0.5 & 0.7 & 0.9 & 3.1 \\
$\left.\mathrm{Temp} .{ }^{\circ} \mathrm{C}\right)$ & $\mathrm{n} / \mathrm{a}$ & 22.4 & 26.0 & 27.3 & 28.5 & 36.0 \\
$\mathrm{Na}(\mathrm{mM})$ & 0.0004 & 0.1 & 0.9 & 1.4 & 2.2 & 11 \\
$\mathrm{Ca}(\mathrm{mM})$ & 0.0002 & 0.2 & 1.1 & 1.6 & 2.5 & 5.9 \\
$\mathrm{Mg}(\mathrm{mM})$ & 0.0004 & 0.09 & 0.5 & 0.8 & 1.2 & 6.2 \\
$\mathrm{Si}(\mathrm{mM})$ & 0.0004 & 0.2 & 0.5 & 0.5 & 0.6 & 1.2 \\
$\mathrm{~K}(\mathrm{mM})$ & 0.0003 & 0.01 & 0.05 & 0.07 & 0.11 & 2.5 \\
$\mathrm{HCO}{ }^{-}(\mathrm{mM})$ & $n / a$ & 0.6 & 4.1 & 5.6 & 7.3 & 22 \\
$\mathrm{Cl}(\mathrm{mM})$ & 0.006 & $<0.006$ & 0.1 & 0.4 & 1.2 & 12.6 \\
$\mathrm{SO}{ }^{2-}(\mathrm{mM})$ & 0.002 & $<0.002$ & 0.02 & 0.13 & 0.4 & 2.4 \\
$\mathrm{NO}{ }_{3}^{-}(\mathrm{mM})$ & 0.003 & $<0.003$ & $<0.003$ & 0.006 & 0.1 & 3.4 \\
$\mathrm{~F}^{-}(\mathrm{mM})$ & 0.003 & $<0.003$ & $<0.003$ & 0.006 & 0.02 & 0.07 \\
$\mathrm{P}(\mathrm{mM})$ & 0.0003 & $<0.0003$ & 0.0004 & 0.002 & 0.003 & 0.06 \\
$\mathrm{Fe}(\mathrm{mM})$ & 0.0002 & $<0.0002$ & 0.0002 & 0.001 & 0.01 & 0.2 \\
$\mathrm{Mn}(\mathrm{mM})$ & 0.0002 & $<0.0002$ & 0.0003 & 0.002 & 0.004 & 0.07 \\
$\mathrm{Zn}(\mu \mathrm{M})$ & 0.02 & 0.02 & 0.11 & 0.24 & 1.1 & 82 \\
$\mathrm{As}(\mu \mathrm{M})$ & 0.01 & $<0.01$ & $<0.01$ & $<0.01$ & 0.06 & 11.6 \\
$\mathrm{U}(\mu \mathrm{M})$ & 0.004 & $<0.004$ & $<0.004$ & 0.009 & 0.03 & 0.4 \\
$\mathrm{Cu}(\mu \mathrm{M})$ & 0.02 & $<0.02$ & $<0.02$ & $<0.02$ & $<0.02$ & 1.2 \\
$\mathrm{~Pb}(\mu \mathrm{M})$ & 0.005 & $<0.005$ & $<0.005$ & $<0.005$ & $<0.005$ & 0.03 \\
\hline & & & & & &
\end{tabular}

An exceedance plot (Figure 4) with relation to WHO guideline values indicates that concentrations of As and $U$ exceed guideline values in $\sim 16 \%$ and $\sim 7 \%$, respectively, of measured samples. Concentrations of Mn exceed the previous WHO guideline in $\sim 15 \%$ of samples. Although this guideline was discontinued in 2011 [150], high Mn groundwater can still be problematic, in particular due to concerns about risks associated with impairment of intellectual function [151] and/or for palpability and aesthetic reasons, and $\mathrm{Mn}$ reduction is a common remediation objective. $\mathrm{NO}_{3}{ }^{-}$exceeds guideline values in $\sim 8 \%$ of samples. Concentrations of $\mathrm{F}^{-}, \mathrm{Ba}, \mathrm{Pb}$ and $\mathrm{Cu}$ are never in exceedance of guidelines for this sample set, however $\mathrm{F}^{-}$in particular is very near guideline values (maximum concentration $0.07 \mathrm{mM}$; guideline value $0.08 \mathrm{mM}$ ) in a number of samples.

Given the particular focus on As and $U$ in this manuscript, and the higher proportion of guideline exceedance for these parameters, histograms and cumulative frequency curves, including with comparison to WHO guideline values, are shown in Figure 5. In particular, we wish to highlight the higher sampling density undertaken in Patna district $(n=62)$ as compared with the overall dataset, in order to assess any potential disproportionate bias this may contribute. A comparison of cumulative frequency distribution curves indicates that although the Patna distribution is very similar to the overall Bihar dataset, Patna groundwater trends towards slightly lower concentrations of both As and $U$ as compared with the overall dataset (shifting the cumulative distribution slightly left for As and slightly up for $\mathrm{U}$ ). This is not expected to have a major influence on the results presented. On the other hand, in some cases sampling was biased to include locations where As had already been reported by co-authors-for example, in a Samastipur district known As "hot spot" location. This "hot spot" has markedly different characteristics than the random sampling would indicate (e.g., the cumulative distribution indicates much higher As than observed in the overall dataset). This has two very important implications on the interpretation presented here: (i) random sampling may miss areas of localized very high concentrations of groundwater contaminants; and (ii) in contrast, only sampling from known "hot spot" areas leads to a significant over-estimation of the concentrations encountered across a wider area. While we endeavoured to undertake representative sampling across 
Bihar, in some cases (e.g., in Samastipur and Buxar districts), our sampling included some sites of expected high As, which thus may bias some of the results reported for those districts. With these exceptions, sampling was conducted in order to minimize any sampling bias as much as possible. While we have endeavoured to undertake representative sampling across Bihar and to report any possible sampling bias with transparency, it is important to note that overall sampling density in this study remained relatively low. Thus, these results can not necessarily be considered comprehensive and in particular may not capture localized influences in particular locations which were not sampled. District-level variations are discussed in detail in Section 3.4.

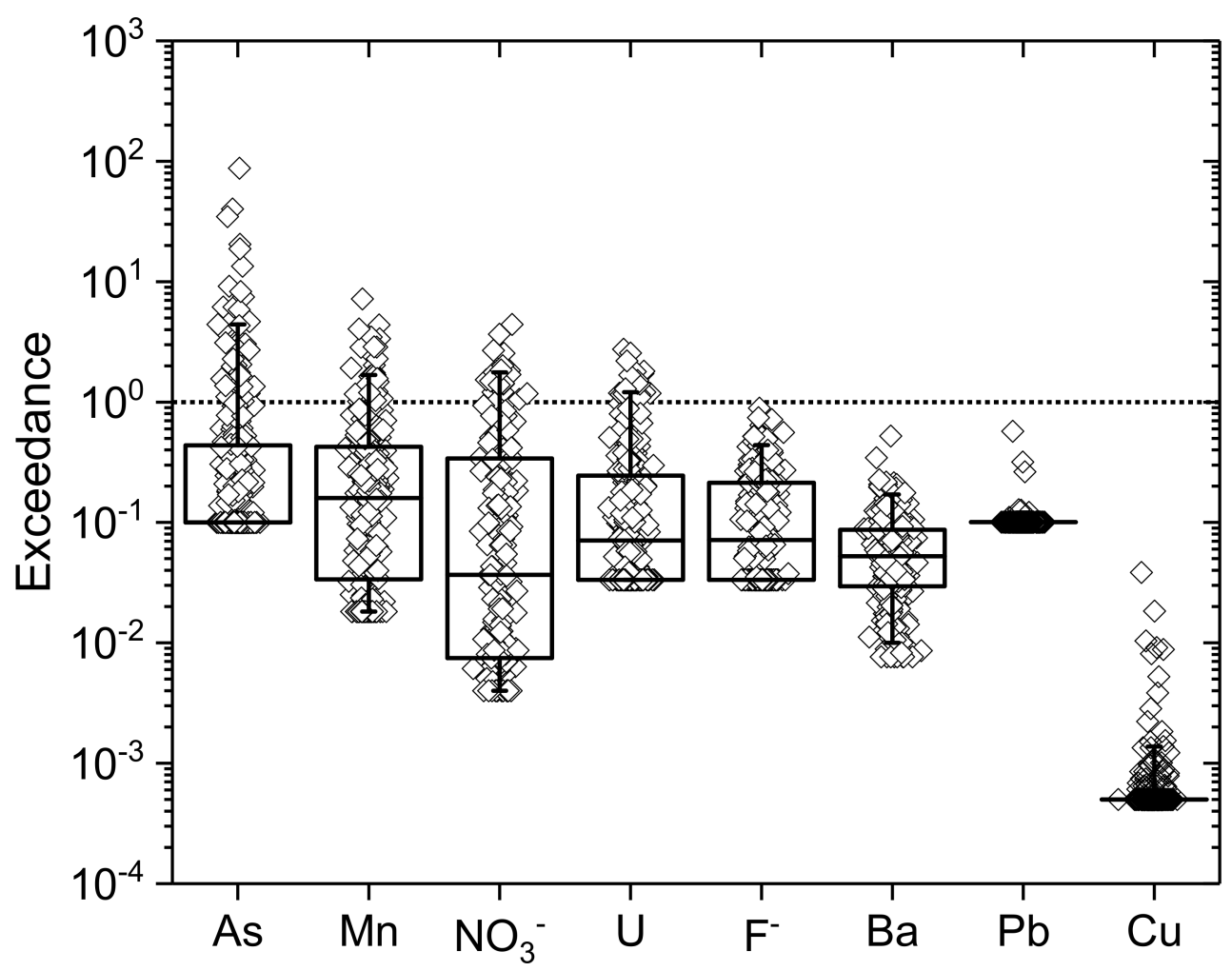

Figure 4. Exceedance plot for measured concentrations against WHO guideline values for As $(0.13 \mu \mathrm{M}$; $10 \mu \mathrm{g} . \mathrm{L}^{-1}$; provisional), Mn (0.01 mM; $0.4 \mathrm{mg} . \mathrm{L}^{-1}$; former/discontinued), $\mathrm{NO}_{3}{ }^{-}\left(0.806 \mathrm{mM} ; 50 \mathrm{mg} . \mathrm{L}^{-1}\right)$, $\mathrm{U}\left(0.13 \mu \mathrm{M} ; 30 \mu \mathrm{g} . \mathrm{L}^{-1}\right.$; provisional), $\mathrm{F}^{-}\left(0.079 \mathrm{mM} ; 1.5 \mathrm{mg} . \mathrm{L}^{-1}\right)$, Ba $\left(0.0095 \mathrm{mM} ; 1.3 \mathrm{mg} . \mathrm{L}^{-1}\right), \mathrm{Pb}(0.048$ $\mu \mathrm{M} ; 0.01 \mathrm{mg} . \mathrm{L}^{-1}$; provisional) and $\mathrm{Cu}\left(0.032 \mathrm{mM} ; 2 \mathrm{mg} . \mathrm{L}^{-1}\right)$. Exceedance was calculated by dividing measured concentrations by the relevant WHO guideline. Exceedance $>1$ indicates the number of samples above guideline values for each parameter (samples with measured concentrations below detection for a particular analyte were calculated based on maximum concentration at method detection limit for inclusion in exceedance plots). Median is line within box; boxes indicate the $25-75$ percentile distribution, whiskers indicate the 5 and 95 percentile distribution. Where median or lower whiskers are not clearly seen there are high numbers of samples below detection. 

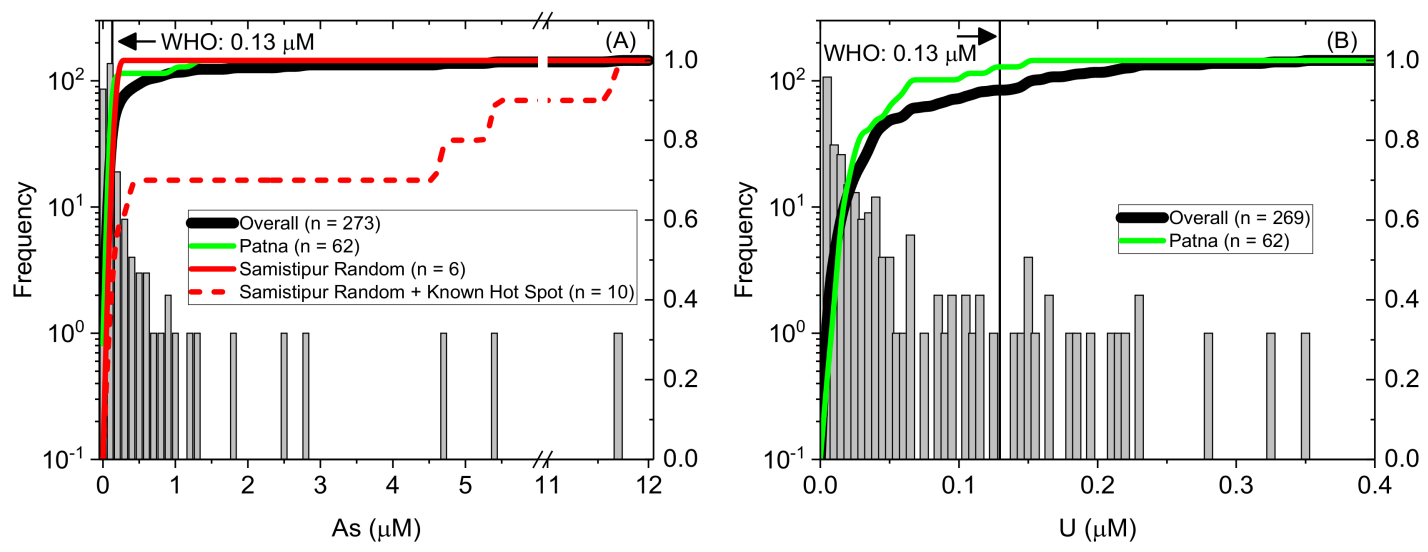

Figure 5. Histogram and cumulative frequency distribution curves for (A) As and (B) $U$ in Bihar, India with WHO provisional guidelines [4] for As $\left(0.13 \mu \mathrm{M} ; 10 \mu \mathrm{g} . \mathrm{L}^{-1}\right)$ and $\mathrm{U}\left(0.13 \mu \mathrm{M} ; 30 \mu \mathrm{g} . \mathrm{L}^{-1}\right)$ shown in solid lines. Histograms are shown for the overall dataset. The cumulative frequencies are included for the overall dataset (bold black line; $n=273$ for As and $n=269$ for $\mathrm{U}$ ) and the Patna district subset (neon green line; $n=62$ ). On (A) two lines for Samastipur are shown indicating one containing random sampling only $(n=6)$ and another with the inclusion of both random and samples from a known As "hot spot" $(n=10)$.

\subsection{Arsenic and Uranium Distribution in Bihar}

The distribution of groundwater As and U across Bihar is presented (Figure 6). Concentrations of As (Figure 6A) tend to be higher in areas near and to the north of the Ganga River, particularly in the zone in between the Gandak and Koshi tributaries to the Ganga and near to the Nepal border. To our knowledge, detailed sampling has not been undertaken in the districts particularly in the far north of Bihar, where elevated As was found in some samples. The highest overall As concentration observed $(11.6 \mu \mathrm{M})$ was in the non-randomized samples from a known "As hotspot" in Samastipur district which has been an area of ongoing investigations by co-authors (see discussion in Section 3.2; also noting that this point is not included on Figure 6A to avoid misinterpretation based on sampling bias). Following that, the highest concentrations were observed in Katihar (east Bihar, max $2.7 \mu \mathrm{M}$ ); Sabalpur (just north of the Ganga opposite Patna; $\max 2.5 \mu \mathrm{M}$ ) and in Buxar (max $1.8 \mu \mathrm{M})$. Both Patna (range $<0.01$ to $1.2 \mu \mathrm{M}, n=62$ ) and Buxar (range $<0.01$ to $1.7 \mu \mathrm{M}, n=15$ ) districts had higher density of sampling, which may explain the wider range of As concentrations encountered in these districts. Areas south of the Ganga are consistently low in As.

The $\sim 16 \%$ of samples here exceeding the WHO limit of $0.13 \mu \mathrm{M}\left(10 \mu \mathrm{g} \cdot \mathrm{L}^{-1}\right)$ [4] is lower than other reports that $\sim 33 \%$ of wells in Bihar ( $\sim 20,000$ ) exceed the same guideline [85]. In part, the higher sampling density in Patna district may contribute to this difference, although not to a major extent (see above discussion). The $\sim 4 \%$ of samples here exceeding the previous Indian standard of $0.65 \mu \mathrm{M}$ (50 $\left.\mu \mathrm{g} . \mathrm{L}^{-1}\right)$ is also lower than that of an earlier study indicating that $\sim 11 \%$ of samples ( $\sim 67,000$, all within $10 \mathrm{~km}$ of the Ganga River) exceeded $0.65 \mu \mathrm{M}$ [77]. Differences could be due to sample size, sampling bias, methodology differences or changing geochemical conditions. Further, this highlights that As concentrations are highly heterogeneous, and suggests that the description of a particular district as simply "As-impacted" may not be particularly meaningful for informing public health risks. Geostatistical modelling of the distribution of groundwater As in Bihar is the subject of ongoing work by co-authors. 


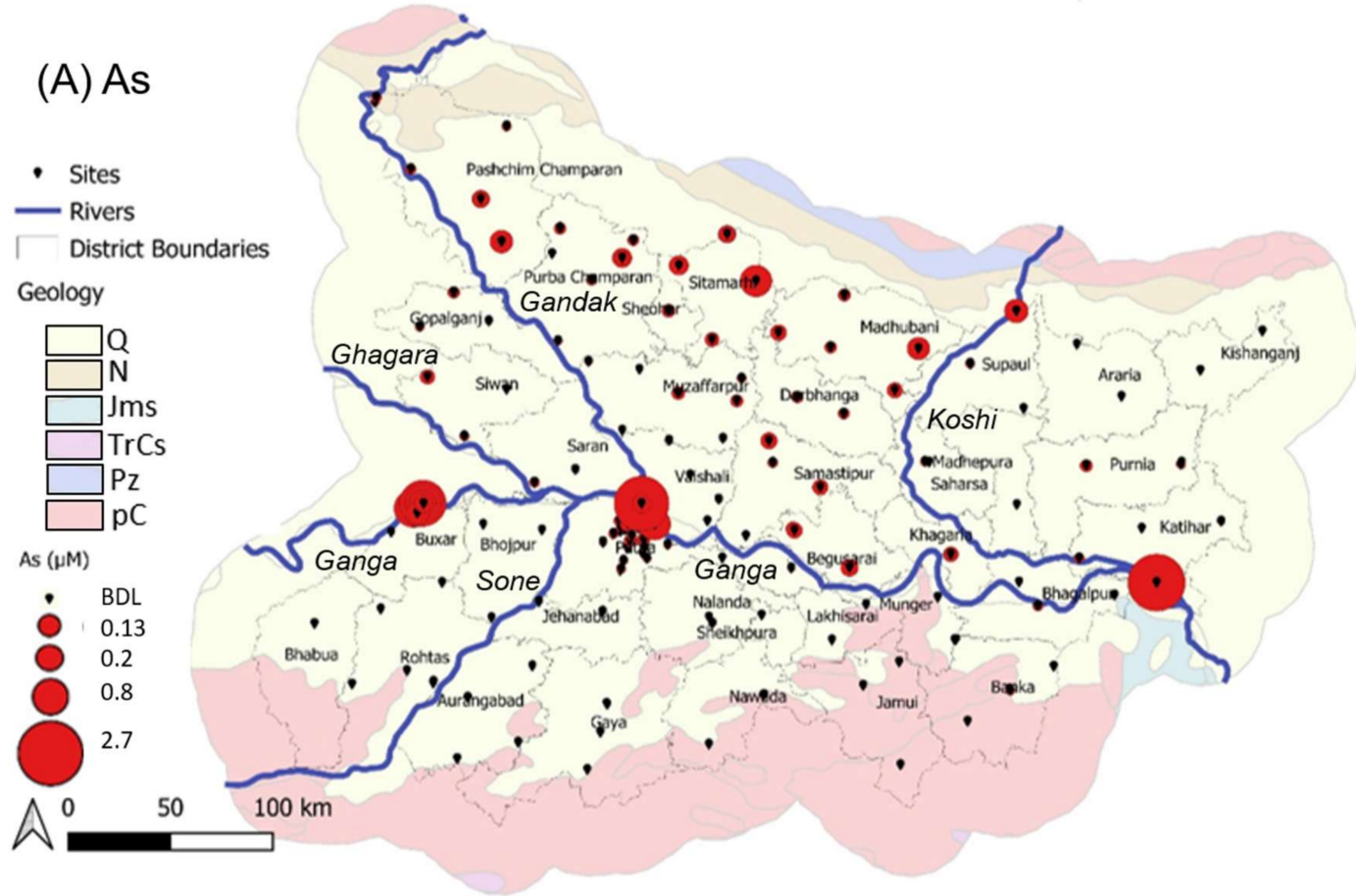

(B) $U$

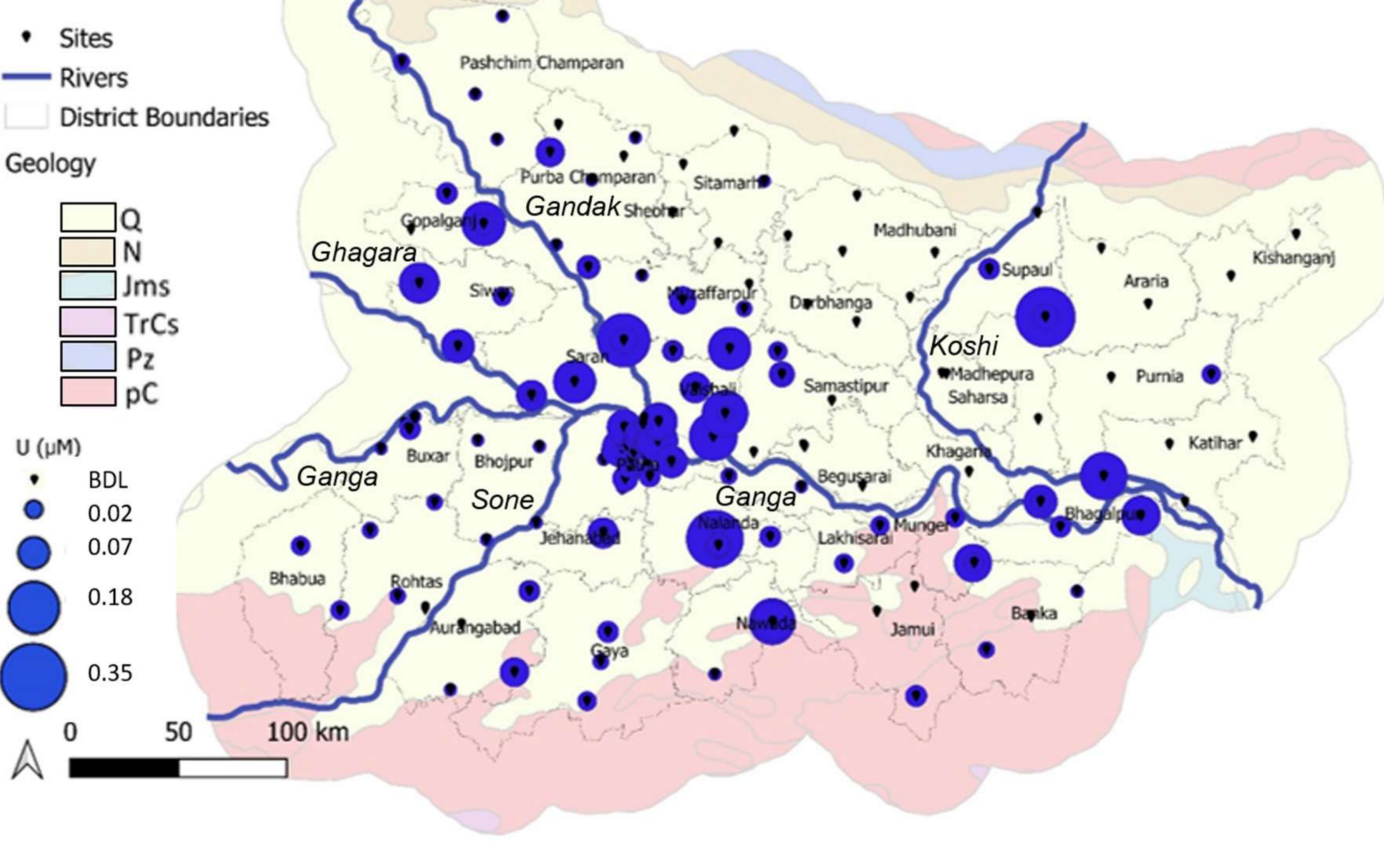

Figure 6. Spatial distribution of (A) As and (B) U in Bihar. Layers from Natural Earth and the US Department of Interior. Geochronological categorization: $\mathrm{Q}=$ Quaternary; $\mathrm{N}=$ Neocene; Jms = Jurassic; $\operatorname{TrCs}=$ Triassic carboniferous; $\mathrm{Pz}=$ Paleozoic; $\mathrm{pC}=$ Pre-Cambrian. $\mathrm{BDL}=$ below detection limit $(0.01 \mu \mathrm{M}$ for As and $0.004 \mu \mathrm{M}$ for $\mathrm{U})$.

In contrast to As, U concentrations (Figure 6B) are elevated mostly in a NW-SE band along and to the east of the Gandak River and running south of the Ganga River towards Jharkhand, particularly in Gopalganj, Siwan, Saran, Patna, Nalanda and Nawada districts. There are also high-U samples in Supaul district ( $\max 0.35 \mu \mathrm{M}$, the highest found in this study), which appear to be more isolated. Elevated $U$ to the south of the Ganga, and especially in the southwestern districts of Aurangabad, 
Gaya, Jahenabad, Nalanda and Nawada, is consistent with previous work in Bihar [102]. In Patna, our results show that $U$ varies significantly and is elevated in some parts of Patna, up to a max of $0.16 \mu \mathrm{M}\left(38 \mu \mathrm{g} . \mathrm{L}^{-1}\right)$; previously $\mathrm{U}$ has been reported to be well below permissible limits in several blocks of Patna [103]. In Singhbhum district (which was previously part of Bihar and now in Jharkhand State), located just south of Bihar, $\mathrm{U}$ mineralization is associated with $\mathrm{Cu}, \mathrm{Ni}$ and sulphides in the Singhbhum shear zone, especially the U-enriched central zone between Jaduguda-Bhatin-Nimdih and Narwapahar-Garadih-Turamdih [152]. Elevated U concentrations have also been found in paleo-interfluvial groundwaters in the Bengal Basin [70]. Similar geological controls may impact the $U$ trends observed here. Consistent with the spatial variability and the differences in redox controls on mobility, groundwater As and $U$ concentrations are strongly inversely correlated (Figure 7; $t(267)=-2.4 ; \mathrm{p}<0.05)$.

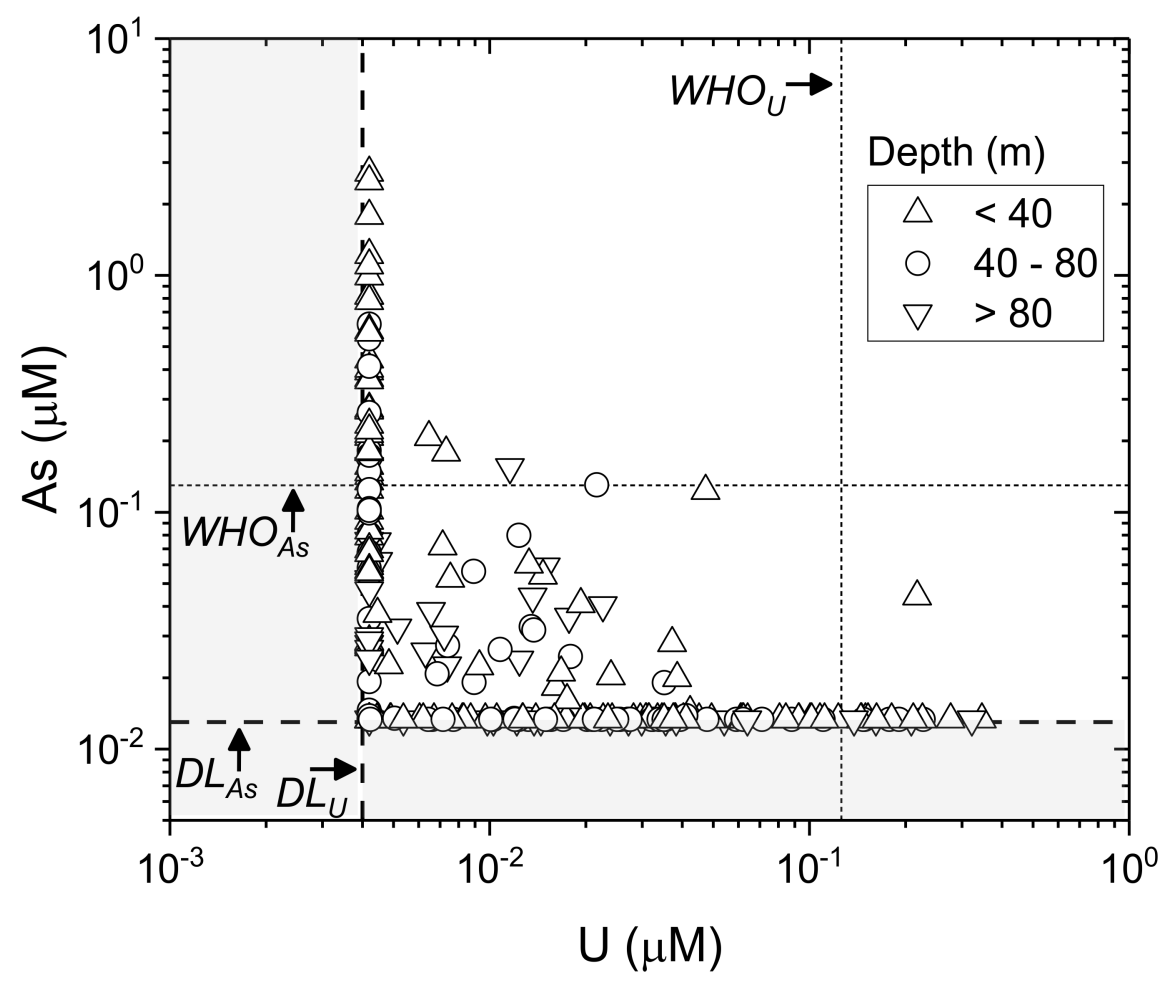

Figure 7. As versus $U$ on a log-scale across the entire field area with WHO provisional guidelines [4] for As $\left(0.13 \mu \mathrm{M} ; 10 \mu \mathrm{g} . \mathrm{L}^{-1}\right)$ and $\mathrm{U}\left(0.13 \mu \mathrm{M} ; 30 \mu \mathrm{g} . \mathrm{L}^{-1}\right)$ in dotted lines (WHO). Samples with measured concentrations below detection for a particular analyte are shown as maximum concentration at method detection limit (DL, shown in dashed lines). Grey boxes emphasize concentrations below method detection limits.

\subsection{Distric-Specific Evaluation}

District-level cumulative frequency distribution curves are shown for As and U (Figure 8). This helps to indicate the comparison at district level and is further supported by a summary of district-level As and U data (Table 2). This shows that the districts where As exceeded WHO provisional guidelines in at least one sample were Begusarai, Buxar, East Champaran, Katihar, Khagaria, Madhubani, Patna, Samastipur, Saran, Sitamarhi, Siwan, Supaul, Vaishali and West Champaran. Districts where U exceeded WHO provisional guidelines in at least one sample were Bhagalpur, Gopalganj, Katihar, Munger, Muzaffarpur, Nalanda, Nawada, Patna, Saran, Siwan, Supaul and Vaishali. There is a very strong geographical control, with districts south of the Ganga typically showing higher (district median) $\mathrm{U}$ and lower (district median) As than districts which are north of the Ganga (Figure 9). 

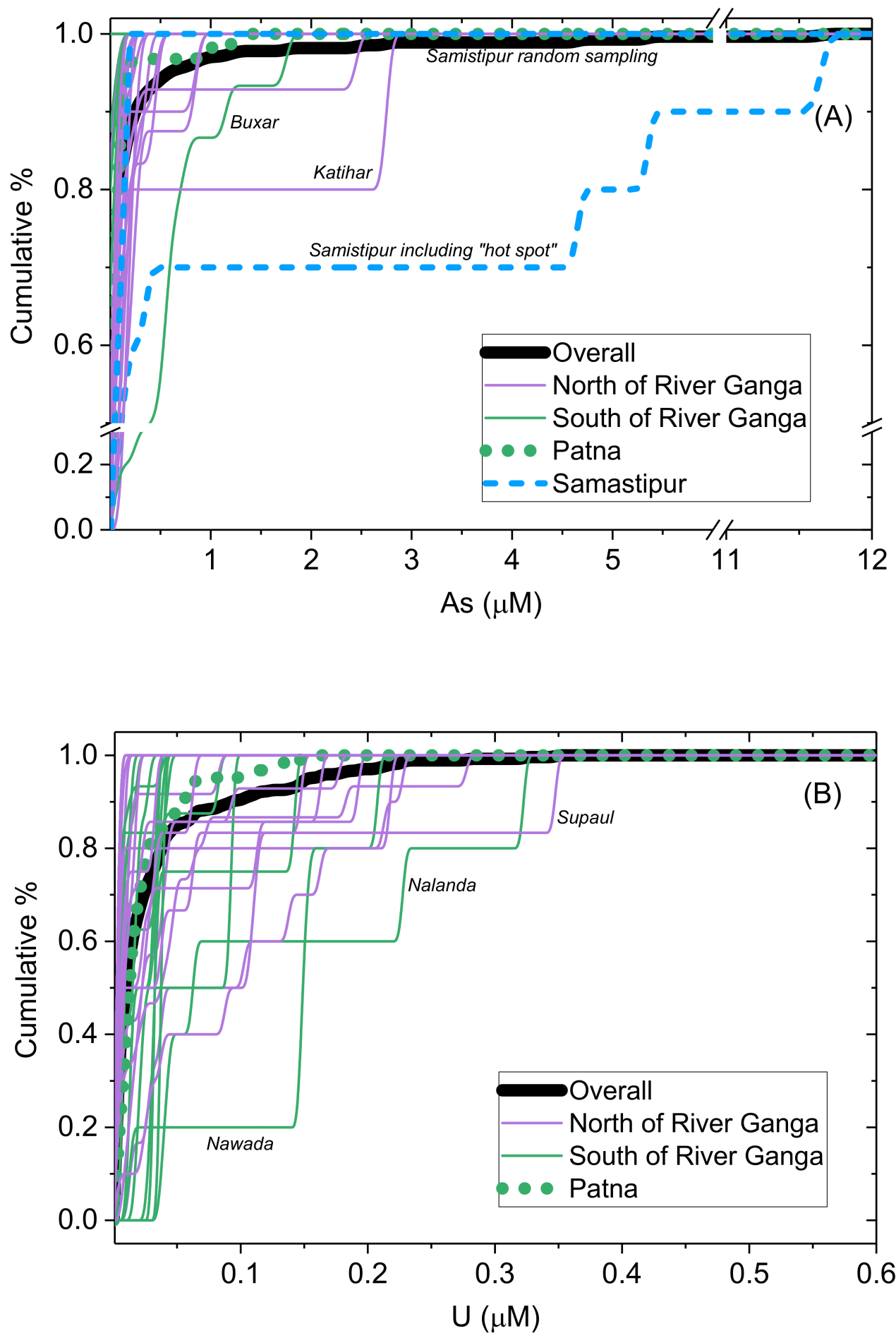

Figure 8. Cumulative distribution curves at a district level for (A) As and (B) U. Overall distribution is shown in bold black line; Patna in green dotted line. On (A), two lines for Samastipur (dashed blue line) are shown, indicating one containing random sampling only and another with the inclusion of samples from a known As "hot spot" (see discussion in Section 3.2). Colours indicate if districts are located north (purple) or south (green) of the River Ganga. 
Table 2. Summary statistics for geochemistry of Bihar groundwater. District-level and overall summary statistics for As and U show minimum, median, mean and maximum concentrations $\left(\mathrm{C}_{\text {min }}, \mathrm{C}_{\text {median }}, \mathrm{C}_{\text {mean }}, \mathrm{C}_{\text {max }}\right.$, respectively) and percentage of samples exceeding WHO provisional guideline values (Ex). WHO provisional guidelines [4] are $0.13 \mu \mathrm{M}\left(10 \mu \mathrm{g} . \mathrm{L}^{-1}\right)$ for As and $0.13 \mu \mathrm{M}\left(30 \mu \mathrm{g} . \mathrm{L}^{-1}\right)$ for $\mathrm{U}$. Bold/underlined font indicate where $\mathrm{C}_{\text {median }}, \mathrm{C}_{\text {mean }}$ or $\mathrm{C}_{\text {max }}$ exceeds WHO guidelines. Samples with measured concentrations below detection for a particular analyte are included as zero in summary statistic calculations.

\begin{tabular}{|c|c|c|c|c|c|c|c|c|c|c|c|}
\hline \multirow{2}{*}{ District } & \multirow{2}{*}{$\mathrm{n}$} & \multicolumn{5}{|c|}{ As } & \multicolumn{5}{|c|}{$\mathrm{U}$} \\
\hline & & $C_{\min }(\mu M)$ & $\mathrm{C}_{\text {median }}(\mu \mathrm{M})$ & $\mathrm{C}_{\text {mean }}(\mu \mathrm{M})$ & $\mathrm{C}_{\max }(\mu \mathrm{M})$ & Ex (\%) & $C_{\min }(\mu M)$ & $\mathrm{C}_{\text {median }}(\mu \mathrm{M})$ & $\mathrm{C}_{\text {mean }}(\mu \mathrm{M})$ & $\mathrm{C}_{\max }(\mu \mathrm{M})$ & Ex (\%) \\
\hline Overall & 273 & $<0.01$ & $<0.01$ & 0.17 & 11.6 & 16 & $<0.004$ & 0.01 & 0.03 & 0.35 & 7 \\
\hline Araria & 2 & $<0.01$ & $<0.01$ & $<0.01$ & $<0.01$ & 0 & $<0.004$ & $<0.004$ & $<0.004$ & $<0.004$ & 0 \\
\hline Arwal & 2 & $<0.01$ & $<0.01$ & $<0.01$ & $<0.01$ & 0 & $<0.004$ & $<0.004$ & $<0.004$ & 0.01 & 0 \\
\hline Aurangabad & 8 & $<0.01$ & $<0.01$ & $<0.01$ & $<0.01$ & 0 & $<0.004$ & 0.01 & 0.02 & 0.08 & 0 \\
\hline Banka & 6 & $<0.01$ & $<0.01$ & $<0.01$ & 0.03 & 0 & $<0.004$ & 0.01 & 0.01 & 0.02 & 0 \\
\hline Begusarai & 4 & 0.12 & 0.16 & 0.16 & 0.21 & 75 & $<0.004$ & $<0.004$ & $<0.004$ & $<0.004$ & 0 \\
\hline Bhagalpur & 6 & $<0.01$ & $<0.01$ & $<0.01$ & 0.04 & 0 & 0.01 & 0.07 & 0.07 & 0.15 & 17 \\
\hline $\begin{array}{l}\text { Bhojpur } \\
\text { Bholp }\end{array}$ & 3 & $<0.01$ & $<0.01$ & $<0.01$ & $<0.01$ & 0 & 0.01 & 0.01 & 0.01 & 0.01 & 0 \\
\hline Buxar & 15 & $<0.01$ & 0.41 & 0.51 & 1.79 & 80 & $<0.004$ & $<0.004$ & 0.004 & 0.04 & 0 \\
\hline Darbhanga & 3 & 0.06 & 0.07 & 0.06 & 0.07 & 0 & $<0.004$ & $<0.004$ & $<0.004$ & $<0.004$ & 0 \\
\hline East Champaran & 12 & $\begin{array}{l}0.00 \\
<0.01\end{array}$ & 0.04 & 0.05 & 0.27 & 8 & $<0.004$ & 0.01 & 0.01 & 0.08 & 0 \\
\hline Gaya & 4 & $<0.01$ & $<0.01$ & $<0.01$ & $<0.01$ & 0 & 0.02 & 0.03 & 0.03 & 0.04 & 0 \\
\hline Gopalganj & 7 & $<0.01$ & 0.02 & 0.02 & 0.07 & 0 & $<0.004$ & 0.02 & 0.04 & 0.19 & 14 \\
\hline Jamui & 6 & $<0.01$ & $<0.01$ & $<0.01$ & $<0.01$ & 0 & $<0.004$ & $<0.004$ & 0.01 & 0.04 & 0 \\
\hline Jehanabad & 2 & $<0.01$ & $<0.01$ & $<0.01$ & $<0.01$ & 0 & 0.01 & 0.05 & 0.05 & 0.09 & 0 \\
\hline Kaimur & 2 & $<0.01$ & $<0.01$ & $<0.01$ & $<0.01$ & 0 & 0.01 & 0.02 & 0.02 & 0.03 & 0 \\
\hline Katihar & 5 & $<0.01$ & $<0.01$ & 0.55 & 2.72 & 20 & $<0.004$ & $<0.004$ & 0.04 & 0.22 & 20 \\
\hline Khagaria & 2 & 0.09 & 0.12 & 0.12 & 0.14 & 50 & $<0.004$ & $<0.004$ & $<0.004$ & $<0.004$ & 0 \\
\hline Kishanganj & 3 & $<0.01$ & $<0.01$ & $<0.01$ & $<0.01$ & 0 & $<0.004$ & $<0.004$ & $<0.004$ & $<0.004$ & 0 \\
\hline Lakhisarai & 2 & $<0.01$ & $<0.01$ & $<0.01$ & $<0.01$ & 0 & 0.03 & 0.03 & 0.03 & 0.03 & 0 \\
\hline Madhepura & 1 & - & $<0.01$ & $<0.01$ & - & 0 & - & 0.004 & 0.004 & - & 0 \\
\hline Madhubani & $\begin{array}{l}1 \\
6\end{array}$ & 0.06 & 0.11 & 0.15 & 0.39 & 50 & $<0.004$ & $\begin{array}{l}0.004 \\
<0.004\end{array}$ & $\begin{array}{l}0.004 \\
<0.004\end{array}$ & $<0.004$ & 0 \\
\hline Munger & 4 & $<0.01$ & $<0.01$ & $<0.01$ & $<0.01$ & 0 & 0.03 & 0.03 & 0.06 & 0.14 & 25 \\
\hline Muzaffarpur & 15 & $<0.01$ & $<0.01$ & 0.02 & 0.10 & 0 & $<0.004$ & 0.04 & 0.05 & 0.28 & 13 \\
\hline Nalanda & 5 & $<0.01$ & $<0.01$ & $<0.01$ & $<0.01$ & 0 & 0.04 & 0.06 & 0.14 & 0.32 & 40 \\
\hline Nawada & 5 & $<0.01$ & $<0.01$ & $<0.01$ & $<0.01$ & 0 & 0.01 & 0.15 & 0.13 & 0.21 & 80 \\
\hline $\begin{array}{l}\text { Patna } \\
\text { Pand }\end{array}$ & 62 & $<0.01$ & $<0.01$ & 0.05 & 1.22 & 5 & $<0.004$ & $\begin{array}{l}0.13 \\
0.01\end{array}$ & $\begin{array}{l}0.13 \\
0.02\end{array}$ & 0.15 & $\begin{array}{c}00 \\
2\end{array}$ \\
\hline Purnia & 4 & $<0.01$ & 0.01 & 0.03 & 0.08 & 0 & $<0.004$ & 0.004 & 0.01 & 0.03 & 0 \\
\hline Rohtas & 7 & $<0.01$ & $<0.01$ & $<0.01$ & $<0.01$ & 0 & $<0.004$ & 0.02 & 0.01 & 0.03 & 0 \\
\hline Saharsa & 2 & $<0.01$ & 0.01 & 0.01 & 0.03 & 0 & $<0.004$ & $<0.004$ & $<0.004$ & 0.005 & 0 \\
\hline Samastipur ${ }^{1}$ & 6 & $<0.01$ & 0.05 & 0.07 & 0.18 & 33 & $<0.004$ & 0.01 & 0.02 & 0.06 & 0 \\
\hline Samastipur ${ }^{2}$ & 10 & $<0.01$ & 0.16 & 2.23 & 11.6 & 60 & - & - & - & - & - \\
\hline Saran & 14 & $<0.01$ & 0.05 & 0.23 & 2.50 & 21 & $<0.004$ & $<0.004$ & 0.02 & 0.18 & 7 \\
\hline Sheikpura & 1 & - & $<0.01$ & $<0.01$ & - & 0 & - & 0.04 & 0.04 & - & 0 \\
\hline Sheohar & 2 & 0.04 & 0.07 & 0.07 & 0.10 & 0 & $<0.004$ & $<0.004$ & $<0.004$ & 0.004 & 0 \\
\hline Sitamarhi & 8 & 0.03 & 0.15 & 0.22 & 0.82 & 50 & $<0.004$ & $<0.004$ & $<0.004$ & 0.01 & 0 \\
\hline Siwan & 7 & $<0.01$ & $<0.01$ & 0.03 & 0.13 & 14 & 0.01 & 0.02 & 0.05 & 0.16 & 14 \\
\hline Supaul & 6 & $<0.01$ & 0.01 & 0.10 & 0.44 & 33 & $<0.004$ & 0.02 & 0.07 & 0.35 & 17 \\
\hline Vaishali & 10 & $<0.01$ & $<0.01$ & 0.08 & 0.82 & 10 & $<0.004$ & 0.09 & 0.10 & 0.23 & 40 \\
\hline West Champaran & 10 & $<0.01$ & 0.04 & 0.10 & 0.40 & 30 & $<0.004$ & 0.01 & 0.01 & 0.02 & 0 \\
\hline
\end{tabular}

${ }^{1}$ Samastipur random sampling set only; ${ }^{2}$ Samastipur set including four samples from a known As "hot spot". 


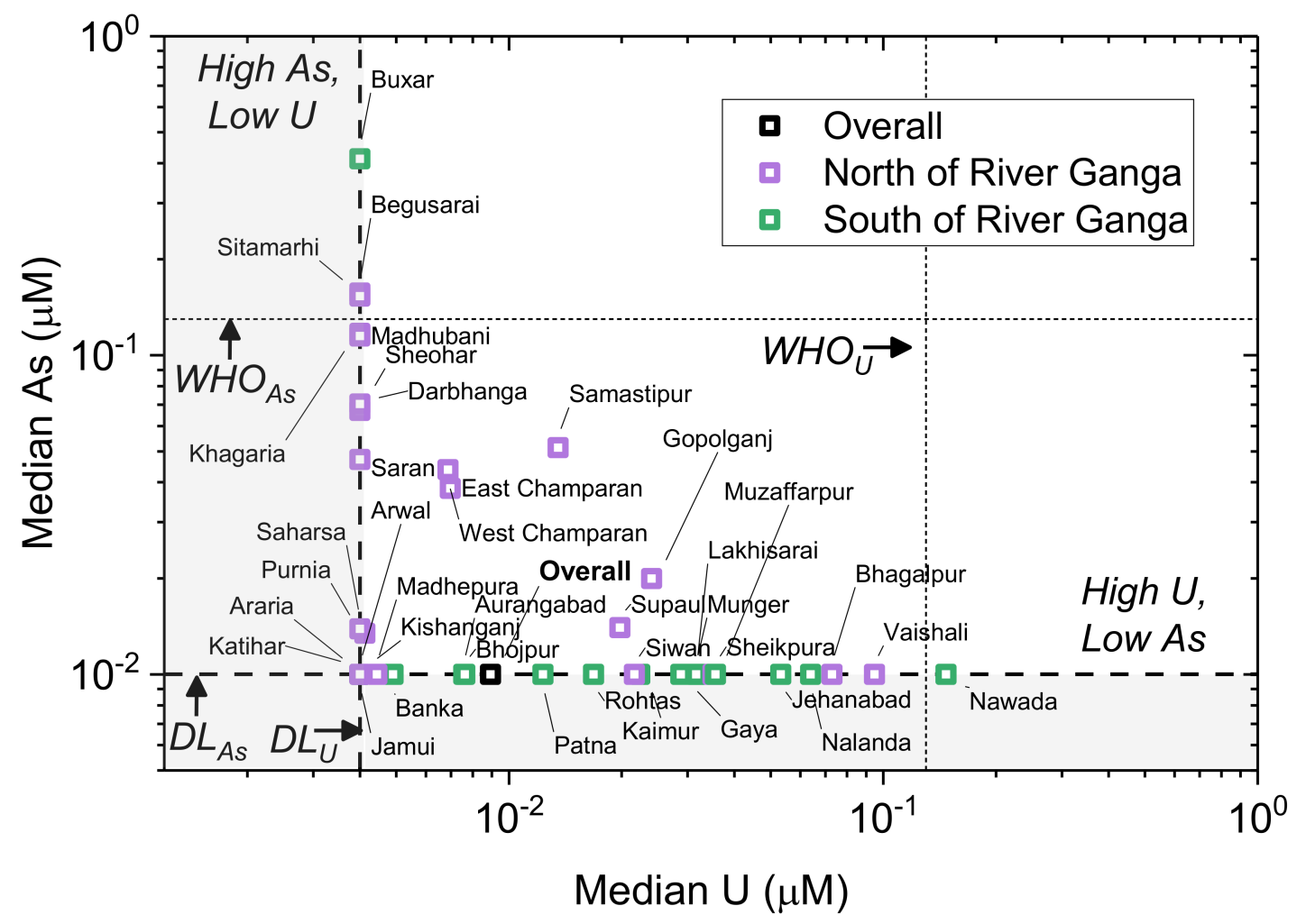

Figure 9. District-level median As versus median U in Bihar with district names labelled and geographic location (e.g., north versus south of Ganga River) indicated in colour. WHO provisional guidelines [4] for both As and U are shown in dotted lines (WHO); method detection limits (DL) for As and U are shown in dashed lines. Grey boxes indicate median concentrations below detection; districts with median concentrations of non-detection are presented at the value of the method detection limit to represent maximum (e.g., most conservative) concentration estimates.

\subsection{Geochemical Controls on Arsenic Mobility}

Concentrations of groundwater As show a broad dependence on depth (Figure 10A) $(t(269)=-1.5 ; p=0.12)$, which is consistent with previous studies, including in Bangladesh [6], Bihar [81,82] and beneath paleo-channels in West Bengal [69]. The highest As is most frequently found in the shallowest depths $(<40 \mathrm{~m})$, however importantly noting that elevated As is still found in some cases at depths of $>100 \mathrm{~m}$. Further, the same depth of groundwater supply can contain As concentrations varying by $>2$ orders of magnitude, highlighting the insufficiency of the anecdotal perception that depth is a suitable proxy for water quality. Depth profiles of Fe (Figure 10B), Mn (Figure 10C) and $\mathrm{SO}_{4}{ }^{2-}$ (Figure 10D) show similar depth dependence, with the highest concentrations of each of these parameters observed in shallow groundwater. Concentrations of As are strongly positively correlated with Fe $(t(267)=10.9 ; p<0.05)$ and $\mathrm{Mn}(t(267)=2.4 ; p<0.05)$, and inversely correlated strongly with $\operatorname{Eh}(t(236)=-2.9 ; p<0.05)$ as well as broadly with $\mathrm{SO}_{4}{ }^{2-}(t(267)=-1.8 ; p=0.07)$. Elevated As associated with $\mathrm{Fe}$ and $\mathrm{Mn}$ in relatively low $\mathrm{Eh}$ and low $\mathrm{SO}_{4}{ }^{2-}$ groundwaters is highly consistent with As mobilization via reductive dissolution of Fe- and/or Mn- (hydr)oxides [26,27,118,153]. Bihar is known to be underlain by a two-tier aquifer system within a depth of $\sim 300 \mathrm{~m}$, separated by a clay/sandy clay aquitard ranging in thickness ranging from $\sim 15-30 \mathrm{~m}$ [81]. Our findings here are consistent with previous observations that shallow (e.g., $<\sim 50 \mathrm{~m}$ ) groundwater is particularly susceptible to As contamination, whereas deeper, confined or semi-confined aquifers typically are lower in As [81]. 


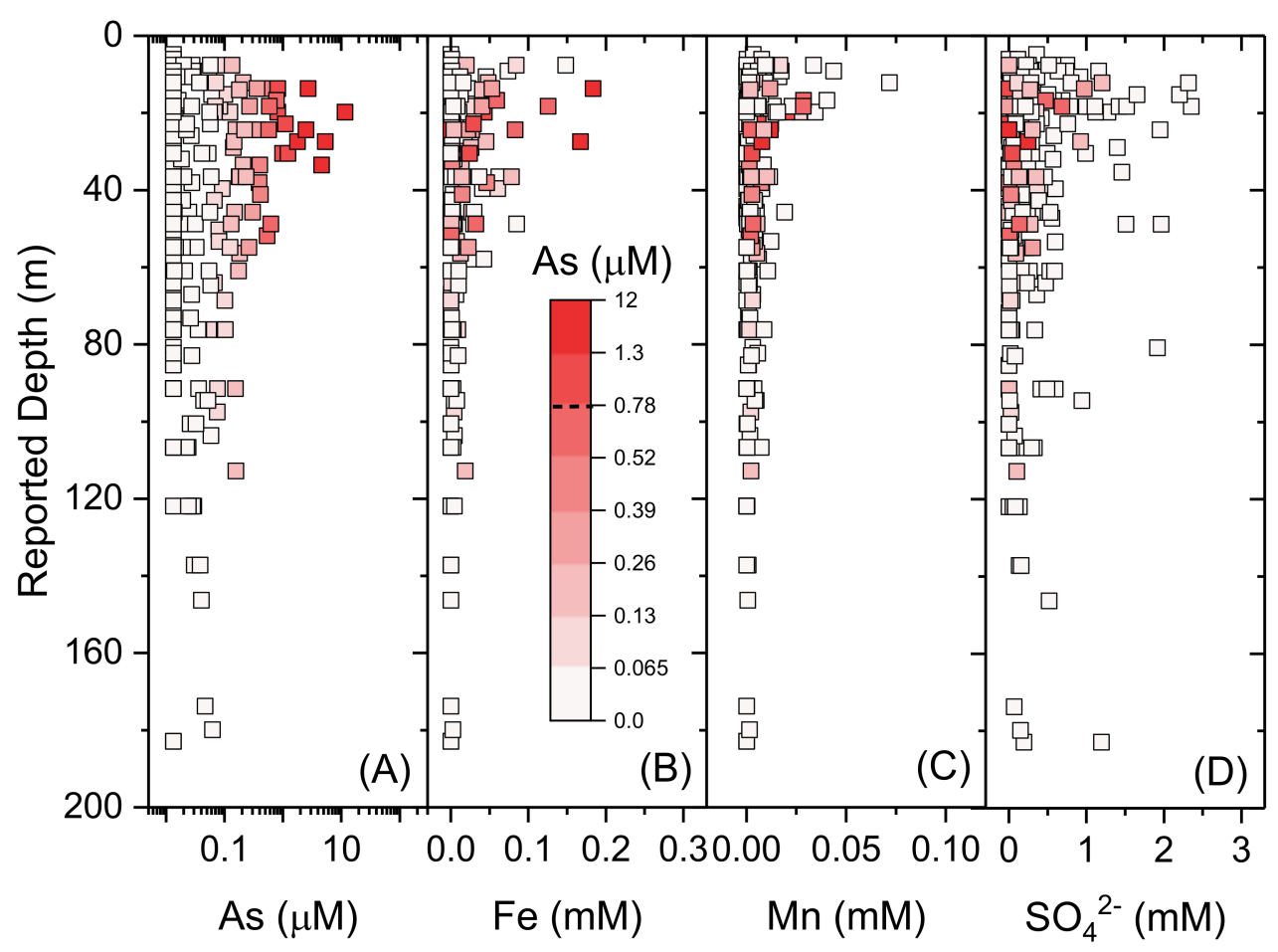

Figure 10. Depth profiles of (A) As (log scale), (B) Fe, (C) Mn and (D) $\mathrm{SO}_{4}{ }^{2-}$; colour scale indicates As concentrations with WHO provisional guideline [4] of $0.13 \mu \mathrm{M}\left(10 \mu \mathrm{g} . \mathrm{L}^{-1}\right)$. Samples with measured concentrations below detection for a particular analyte are shown as maximum concentration at method detection limit.

\subsection{Geochemical Controls on Uranium Mobility}

The geochemical conditions favourable to support $U$ release and/or mobility are strongly in contrast to those conditions in which As is present. $\mathrm{U}$ is instead associated with more oxidizing conditions, exhibiting a strong positive correlation with $E h(t(232)=3.5 ; p<0.05))$. Further, $\mathrm{U}$ is strongly correlated both with $\mathrm{HCO}_{3}{ }^{-}$(Figure 11A; $\left.t(267)=5.1 ; p<0.05\right)$ and with $\mathrm{NO}_{3}{ }^{-}$(Figure 11B; $t(267)=4.6 ; p<0.05)$. In contrast, for As, there is no statistically significant relationship with $\mathrm{HCO}_{3}{ }^{-}$ nor $\mathrm{NO}_{3}{ }^{-}(p>0.05$ for both; Figure 11C,D). There is no apparent relationship between $\mathrm{U}$ and depth $(t(265)=-0.5 ; p=0.6)$ (Figure 12).

The contrasting As and $U$ behaviours can be examined more closely by looking at various bivariate relationships (Figure 13). It is apparent that within the relationship between $\mathrm{Mn}$ and Fe (Figure 13A,B), high As is associated with high Mn and Fe (consistent with Figure 10), whereas the high U trends toward lower values of $\mathrm{Fe}$ in particular. Similar clustering of high-As groundwater is observed with high $\mathrm{Fe}$ and low $\mathrm{SO}_{4}{ }^{2-}: \mathrm{Cl}$ (molar ratio), whereas $\mathrm{U}$ is associated with higher $\mathrm{SO}_{4}{ }^{2-}: \mathrm{Cl}$ (Figure 13E,F). High As is correlated with relatively higher $\mathrm{pH}$ values, low $\mathrm{Eh}$ and lower $\mathrm{HCO}_{3}{ }^{-}$, whereas $\mathrm{U}$ trends towards lower $\mathrm{pH}$ and particularly higher $\mathrm{Eh}$ and $\mathrm{HCO}_{3}{ }^{-}$(Figure $13 \mathrm{C}, \mathrm{D}, \mathrm{G}, \mathrm{H}$ ). A detailed investigation regarding the impact of surface-derived organic matter ingress, and associated changing redox conditions in the subsurface, on As mobilization in Patna, Bihar is the subject of ongoing work by co-authors. 

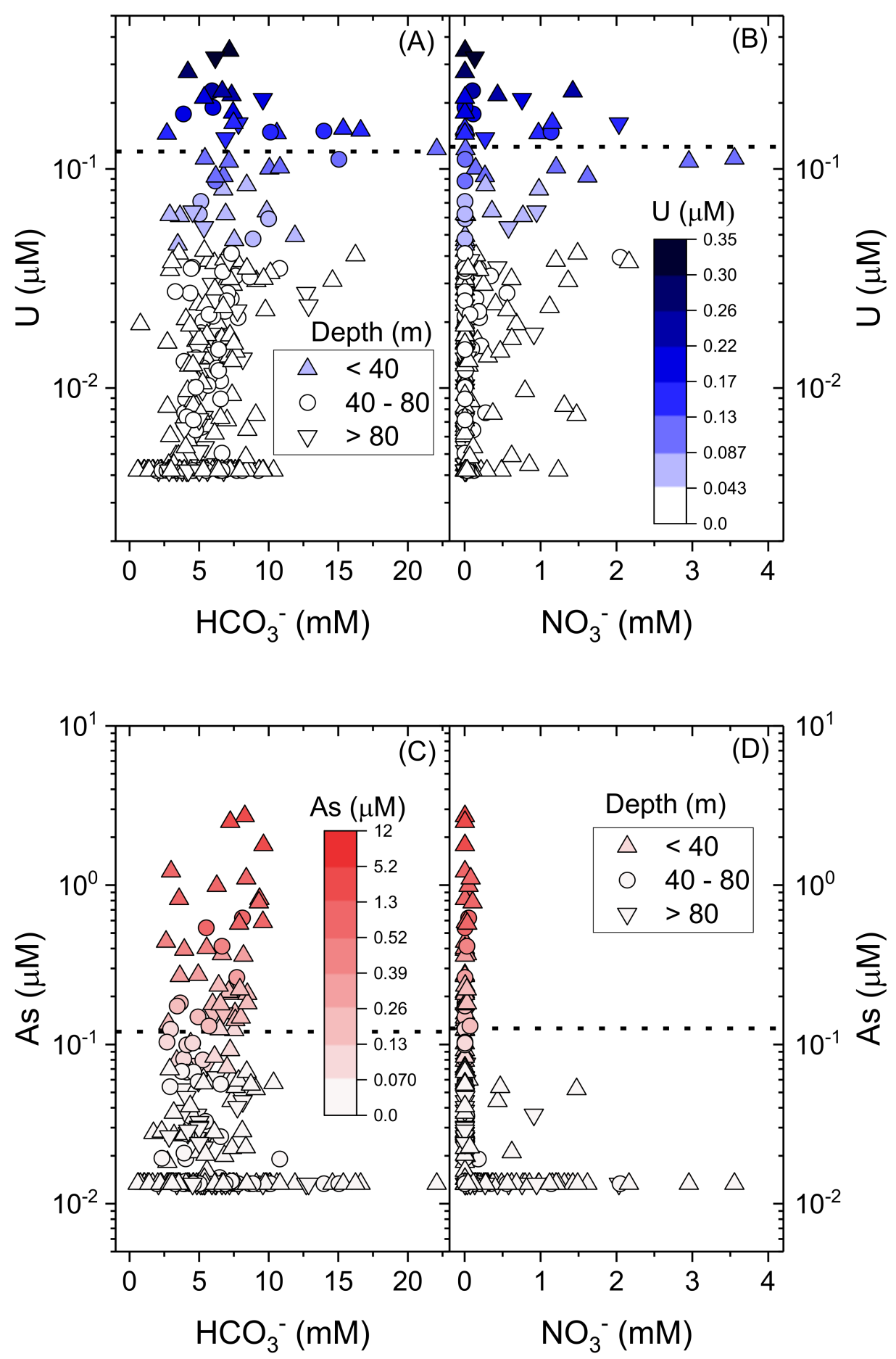

Figure 11. $\mathrm{U}$ (log-scale) versus (A) estimated $\mathrm{HCO}_{3}{ }^{-}$and (B) $\mathrm{NO}_{3}{ }^{-}$with the WHO provisional guideline [4] of $0.13 \mu \mathrm{M}\left(30 \mu \mathrm{g} . \mathrm{L}^{-1}\right)$ for $\mathrm{U}$ in dotted line. As (log-scale) versus (C) estimated $\mathrm{HCO}_{3}{ }^{-}$ and (D) $\mathrm{NO}_{3}{ }^{-}$with the WHO provisional guideline [4] of $0.13 \mu \mathrm{M}\left(10 \mu \mathrm{g} . \mathrm{L}^{-1}\right)$ for As in dotted line. Symbol shape indicates reported depth; colour scale indicates $U$ (blue) and As (red) concentrations. Samples with measured concentrations below detection for a particular analyte are shown as maximum concentration at method detection limit. 


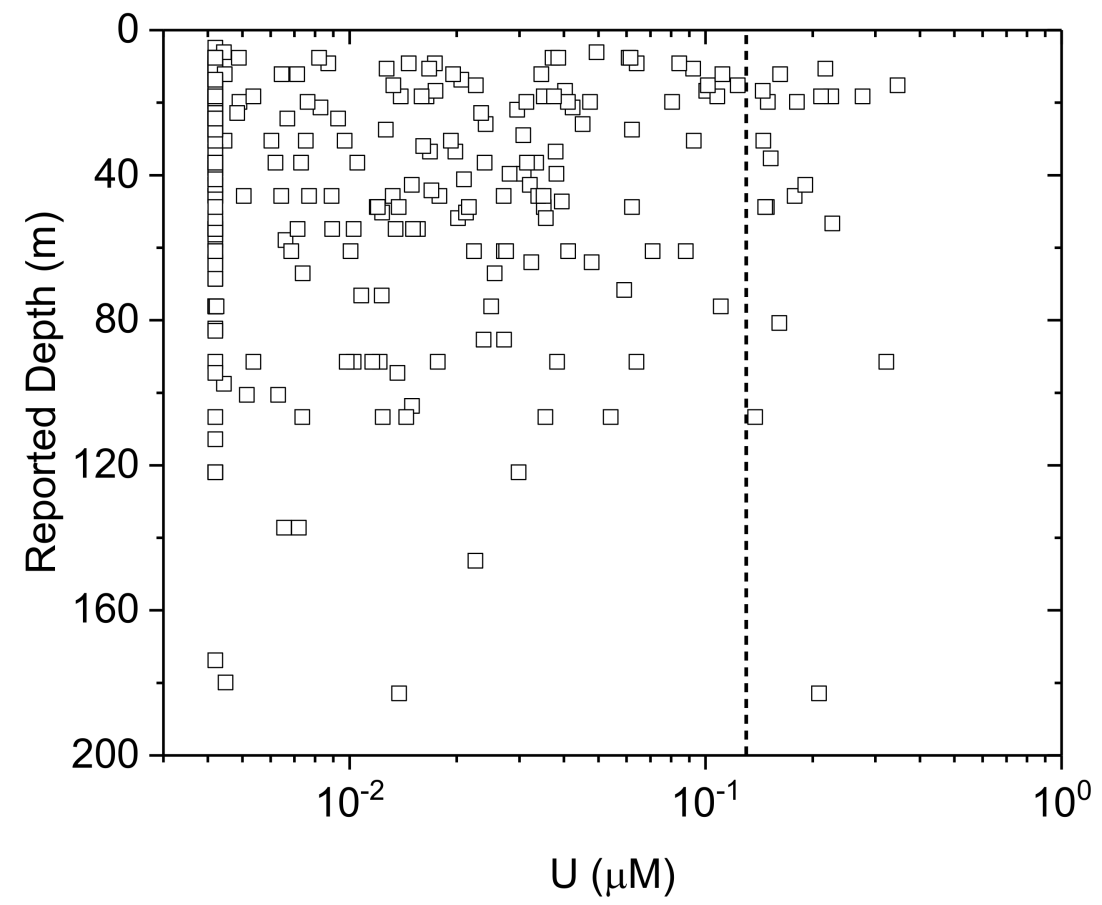

Figure 12. Depth versus U (log-scale) with the WHO provisional guideline [4] of $0.13 \mu \mathrm{M}\left(30 \mu \mathrm{g} . \mathrm{L}^{-1}\right)$ for $U$ in dotted line. Samples with measured concentrations below detection are shown as maximum concentration at method detection limit.
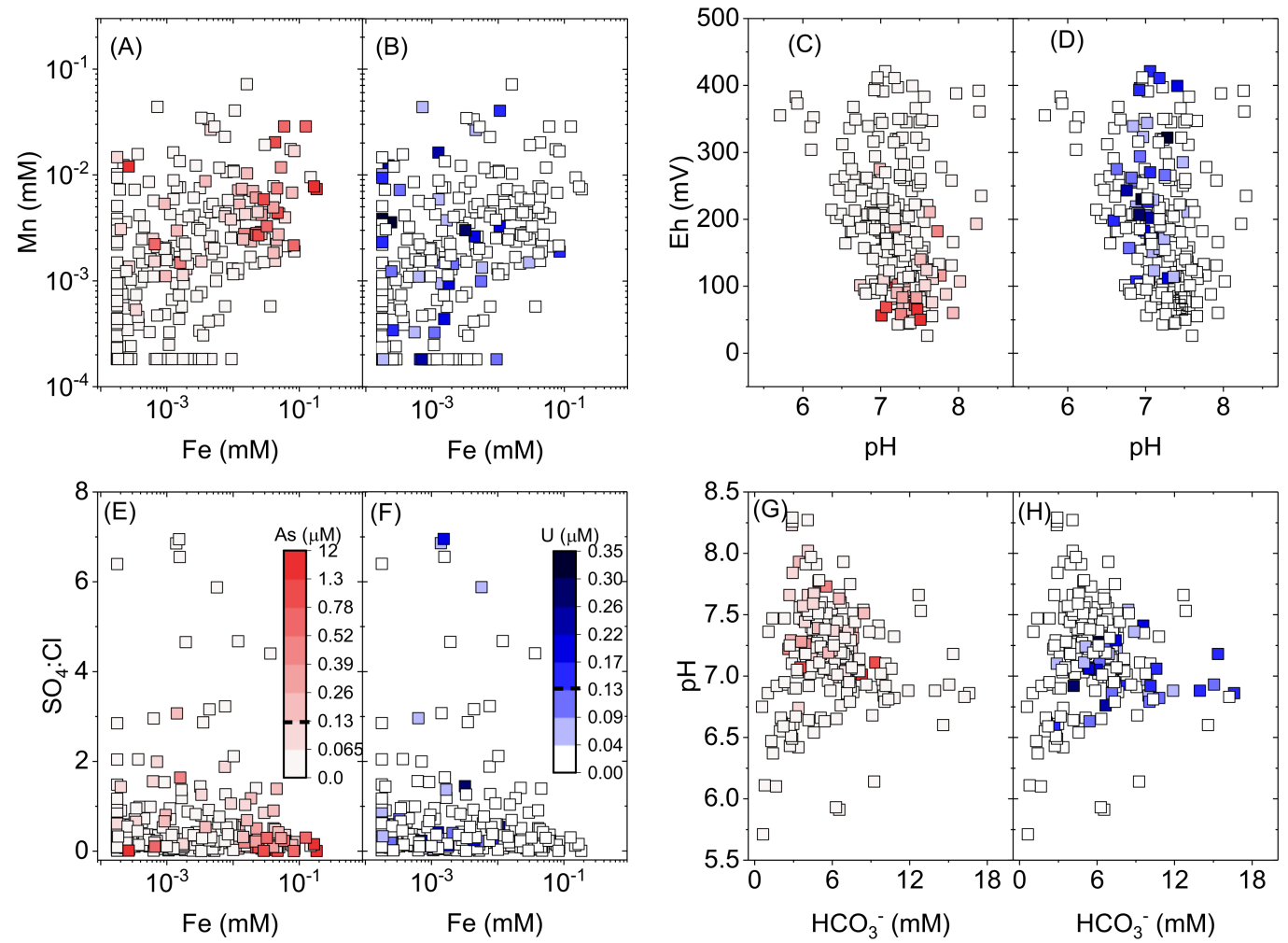

Figure 13. Bivariate plots for (A,B) Mn versus $\mathrm{Fe}$; (C,D) Eh versus $\mathrm{pH} ;(\mathbf{E}, \mathbf{F}) \mathrm{SO}_{4}{ }^{2-}: \mathrm{Cl}^{-}$(molar ratio) versus $\mathrm{Fe}$; and $(\mathbf{G}, \mathbf{H}) \mathrm{pH}$ versus estimated $\mathrm{HCO}_{3}{ }^{-}$. Red colour scales $(\mathbf{A}, \mathbf{C}, \mathbf{E}, \mathbf{G})$ represent As concentrations, and blue colour scales $(\mathbf{B}, \mathbf{D}, \mathbf{F}, \mathbf{H})$ represent $\mathrm{U}$ concentrations. Samples with measured concentrations below detection for a particular analyte are shown as maximum concentration at method detection limit. 


\section{Conclusions}

In this study we characterize the inorganic major and trace element geochemistry in groundwater sources typically used for drinking across all districts of Bihar, India, with a particular focus on As, $\mathrm{U}$ and associated parameters. In Bihar, the dominant groundwater type is $\mathrm{Ca}-\mathrm{HCO}_{3}{ }^{-}$type, with some samples instead $\mathrm{Na}_{-} \mathrm{HCO}_{3}{ }^{-}$type. Concentrations of As and $\mathrm{U}$ exceeded $\mathrm{WHO}$ (provisional) guideline values in $\sim 16 \%$ and $7 \%$ of samples, respectively, as well as $\mathrm{Mn}(\sim 15 \%)$ and $\mathrm{NO}_{3}{ }^{-}(\sim 8 \%)$. Concentrations of $\mathrm{F}^{-}, \mathrm{Ba}, \mathrm{Pb}$ and $\mathrm{Cu}$ were not observed to exceed guideline values in this sample set. Groundwater As and $U$ were strongly inversely correlated, with higher As generally prevalent in reducing conditions and near and to the north of the Ganga river, and higher U typically in oxidizing conditions, particularly located in a NW-SE band running near and to the east of the Gandak River and to the south of the Ganga River. Concentrations of As were positively correlated with Fe and Mn, and inversely correlated with Eh, which is consistent with the mechanism of reductive dissolution of Fe- and/or Mn(hydr)oxides. The strong depth-dependence of As is consistent with previous studies in Bihar and elsewhere in S/SE Asia. In contrast, elevated uranium was positively associated with $E h, \mathrm{HCO}_{3}{ }^{-}$and $\mathrm{NO}_{3}{ }^{-}$, with no apparent dependence on depth. Despite the relatively low sampling density, the spatial coverage across all districts in Bihar provides, for the first time, a comprehensive and consistent dataset for (inorganic) geochemical groundwater characterization in Bihar. These results have important implications for remediation priorities and the selection of appropriate remediation strategies, as well as for identifying areas where further representative sampling and/or monitoring may be beneficial.

Author Contributions: Conceptualization, D.A.P., A.G. (Ashok Ghosh), and L.A.R.; methodology, L.A.R. and D.A.P.; validation, A.K., A.G. (Ashok Ghosh), L.A.R. and D.A.P.; formal analysis, L.A.R.; investigation, L.A.R.; A.K.; P.S.; A.G. (Aman Gaurav); resources, D.A.P. and L.A.R.; data curation, L.A.R.; writing-original draft preparation, L.A.R.; writing-review and editing, All; visualization, L.A.R.; supervision, D.A.P. and L.A.R.; project administration, L.A.R. and D.A.P.; funding acquisition, D.A.P.; A.G. (Ashok Ghosh); L.A.R. All authors have read and agreed to the published version of the manuscript.

Funding: This research was funded by a Department of Science and Technology (DST, India)-Newton Bhabha -Natural Environmental Research Council (NERC, UK)-Engineering and Physical Sciences Research Council (EPSRC, UK) Indo-UK Water Quality Programme award (NE/R003386/1 and DST/TM/INDO-UK/2K17/55(C) \& 55(G); 2018-2021 to DP et al.) and a EPSRC IAA award via University of Manchester to DP et al., with additional support from a Dame Kathleen Ollerenshaw Fellowship to LR.

Acknowledgments: Neha Kumari (formerly Mahavir Cancer Sansthan) is thanked for contributions to the early discussions pertaining to this work. Paul Lythgoe and Alastair Bewsher (The University of Manchester) are thanked for analytical support. Gianfranco Pincetti Zúñiga is thanked for training and support with QGIS. Graham Craik is thanked for assistance with data entry. Finally, we are greatly appreciative of the support and kindness of hundreds of local people of Bihar who allowed us sampling access. We thank the anonymous reviewers for thorough and constructive comments. The views expressed here do not necessarily represent those of the institutions, funders or individuals whose support is acknowledged.

Conflicts of Interest: The authors declare no conflict of interest. The funders had no role in the design of the study; in the collection, analyses, or interpretation of data; in the writing of the manuscript, or in the decision to publish the results.

\section{References}

1. Smedley, L.P.; Kinniburgh, D.G. A review of the source, behaviour and distribution of arsenic in natural waters. Appl. Geochem. 2002, 17, 517-568. [CrossRef]

2. Charlet, L.; Polya, D.A. Arsenic in Shallow, Reducing Groundwaters in Southern Asia: An Environmental Health Disaster. Elements 2006, 2, 91-96. [CrossRef]

3. Ravenscroft, P.; Brammer, H.; Richards, K. Arsenic Pollution-A Global Synthesis. Royal Geographical Society with IBG; Wiley-Blackwell: Chichester, UK, 2009; p. 588.

4. World Health Organization. Guidelines for Drinking-Water Quality, 4th ed.; World Health Organization: Geneva, Switzerland, 2011.

5. Smith, A.H.; Lingas, E.O.; Rahman, M. Contamination of drinking-water by arsenic in Bangladesh: A public health emergency. Bull. World Health Organ. 2000, 78, 1093-1103. [PubMed] 
6. Harvey, C.F.; Swartz, C.H.; Badruzzaman, A.B.M.; Keon-Blute, N.; Yu, W.; Ashraf Ali, M.; Jay, J.; Beckie, R.; Niedan, V.; Brabander, D.; et al. Arsenic mobility and groundwater extraction in Bangladesh. Science 2002, 298, 1602-1606. [CrossRef]

7. Kinniburgh, D.G.; Smedley, P.L. Arsenic Contamination of Groundwater in Bangladesh, Vol. 2: Final Report, in BGS Technical Report WC/00/19; British Geological Survey: Nicker Hill, UK, 2001; Volume 2.

8. Ahmed, K.M.; Bhattacharua, P.; Hasan, M.A.; Akhter, S.H.; Alam, S.M.M.; Bhuian, M.A.H.; Khan, A.A.; Sracek, O. Arsenic enrichment in groundwater of the alluvial aquifers in Bangladesh: An overview. Appl. Geochem. 2004, 19, 181-200. [CrossRef]

9. Horneman, A.; van Geen, A.; Kent, D.V.; Mathe, P.E.; Zheng, Y.; Dhar, R.K.; O'Connell, S.; Moque, M.A.; Aziz, Z.; Shamsudduha, M.; et al. Decoupling of As and Fe release to Bangladesh groundwater under reducing conditions. Part I: Evidence from sediment profiles. Geochim. Et Cosmochim. Acta 2004, 68, 3459-3473. [CrossRef]

10. Van Geen, A.; Protus, T.; Cheng, Z.; Horneman, A.; Seddique, A.A.; Hoque, M.A.; Ahmed, K.M. Testing groundwater for arsenic in Bangladesh before installing a well. Environ. Sci. Technol. 2004, 38, 6783-6789. [CrossRef]

11. Neumann, R.B.; Ashfaque, K.N.; Badruzzaman, A.B.M.; Ali, M.A.; Shoemaker, J.K.; Harvey, C.F. Anthropogenic influences on groundwater arsenic concentrations in Bangladesh. Nat. Geosci. 2010, 3, 46-52. [CrossRef]

12. Yu, W.H.; Harvey, C.M.; Harvey, C.F. Arsenic in groundwater in Bangladesh: A geostatistical and epidemiological framework for evaluating health effects and potential remedies. Water Resour. Res. 2003, 39, 1146-1163. [CrossRef]

13. Bhattacharya, P.; Jacks, G.; Ahmed, K.M.; Routh, J.; Khan, A.A. Arsenic in Groundwater of the Bengal Delta Plain Aquifers in Bangladesh. Bull. Environ. Contam. Toxicol. 2002, 69, 538-545. [CrossRef]

14. McArthur, J.; Ravenscroft, P.; Safiulla, S.; Thirwall, M.F. Arsenic in groundwater: Testing pollution mechanisms for sedimentary aquifers in Bangladesh. Water Resour. Res. 2001, 37, 109-117. [CrossRef]

15. Nickson, R.T.; McArthur, J.M.; Burgess, W.G.; Ahmed, K.M.; Ravenscroft, P.; Rahman, M. Arsenic poisoning of Bangladesh groundwater. Nature 1998, 395, 338. [CrossRef] [PubMed]

16. Polya, D.A.; Gault, A.G.; Bourne, N.J.; Lythgoe, P.R.; Cooke, D.A. Coupled HPLC-ICP-MS analysis indicates highly hazardous concentrations of dissolved arsenic species in Cambodian groundwaters. R. Soc. Chem. Spec. Publ. 2003, 288, 127-140.

17. Polya, D.A.; Gault, A.G.; Diebe, N.; Feldman, P.; Rosenboom, J.W.; Gilligan, E.; Fredericks, D.; Milton, A.H.; Sampson, M.; Rowland, H.A.L.; et al. Arsenic hazard in shallow Cambodian groundwaters. Mineral. Mag. 2005, 69, 807-823. [CrossRef]

18. Tamura, T.; Saito, Y.; Sieng, S.; Ben, B.; Kong, M.; Choup, S.; Tsukawaki, S. Depositional facies and radiocarbon ages of a drill core from the Mekong River lowland near Phnom Penh, Cambodia: Evidence for tidal sedimentation at the time of Holocene maximum flooding. J. Asian Earth Sci. 2007, 29, 585-592. [CrossRef]

19. Benner, S.G.; Polizzotto, M.L.; Kocar, B.D.; Ganguly, S.; Phan, K.; Ouch, K.; Sampson, M.; Fendorf, S. Groundwater flow in an arsenic-contaminated aquifer, Mekong Delta, Cambodia. Appl. Geochem. 2008, 23, 3072-3087. [CrossRef]

20. Kocar, B.D.; Polizzotto, M.L.; Benner, S.G.; Ying, S.C.; Ung, M.; Ouch, K.; Samreth, S.; Suy, B.; Phan, K.; Sampson, M.; et al. Integrated biogeochemical and hydrologic processes driving arsenic release from shallow sediments to groundwaters of the Mekong delta. Appl. Geochem. 2008, 23, 3059-3071. [CrossRef]

21. Polizzotto, M.L.; Kocar, B.D.; Benner, S.G.; Sampson, M.; Fendorf, S. Near-surface wetland sediments as a source of arsenic release to ground water in Asia. Nature 2008, 454, 505-508. [CrossRef]

22. Rowland, H.A.L.; Gault, A.G.; Lythgoe, P.; Polya, D.A. Geochemistry of aquifer sediments and arsenic-rich groundwaters from Kandal Province, Cambodia. Appl. Geochem. 2008, 23, 3029-3046. [CrossRef]

23. Van Dongen, B.; Rowland, H.A.L.; Gault, A.G.; Polya, D.A.; Bryant, C.; Pancost, R.D. Hopane, sterane and n-alkane distributions in shallow sediments hosting high arsenic groundwaters in Cambodia. Appl. Geochem. 2008, 23, 3047-3058. [CrossRef]

24. Polya, D.A.; Charlet, L. Rising arsenic risk? Nat. Geosci. 2009, 2, 383-384. [CrossRef] 
25. Lawson, M.; Polya, D.A.; Boyce, A.J.; Bryant, C.; Mondal, D.; Shantz, A.; Ballentine, C.J. Pond-derived organic carbon driving changes in arsenic hazard found in Asian groundwaters. Environ. Sci. Technol. 2013, 47, 7085-7094. [CrossRef] [PubMed]

26. Lawson, M.; Polya, D.A.; Boyce, A.J.; Bryant, C.; Ballentine, C.J. Tracing organic matter composition and distribution and its role on arsenic release in shallow Cambodian groundwaters. Geochim. Cosmochim. Acta 2016, 178, 160-177. [CrossRef]

27. Richards, L.A.; Magnone, D.; Sovann, C.; Kong, C.; Uhlemann, S.; Kuras, O.; van Dongen, B.E.; Ballentine, C.J.; Polya, D.A. High Resolution Profile of Inorganic Aqueous Geochemistry and Key Redox Zones in an Arsenic Bearing Aquifer in Cambodia. Sci. Total Environ. 2017, 590, 540-553. [CrossRef] [PubMed]

28. Richards, L.A.; Magnone, D.; Sültenfuß, J.; Chambers, L.; Bryant, C.; Boyce, A.J.; van Dongen, B.E.; Ballentine, C.J.; Sovann, C.; Uhlemann, S.; et al. Dual in-aquifer and near surface processes drive arsenic mobilization in Cambodian groundwaters. Sci. Total Environ. 2019, 659, 699-714. [CrossRef] [PubMed]

29. Richards, L.A.; Lapworth, D.J.; Gooddy, D.C.; Chambers, L.; Williams, P.J.; van Dongen, B.E.; Polya, D.A. Dissolved organic matter tracers reveal contrasting characteristics across high arsenic aquifers in Cambodia: A fluorescence spectroscopy study. Geosci. Front. 2019, 10, 1653-1667. [CrossRef]

30. Mai, N.T.H.; Postma, D.; Trang, P.T.K.; Jessen, S.; Viet, P.H.; Larsen, F. Adsorption and desorption of arsenic to aquifer sediment on the Red River floodplain at Nam Du, Vietnam. Geochim. Cosmochim. Acta 2014, 142, 587-600. [CrossRef]

31. Berg, M.; Tran, H.C.; Nguyen, T.C.; Pham, H.V.; Schertenleib, R.; Giger, W. Arsenic contamination of groundwater and drinking water in Vietnam: A human health threat. Environ. Sci. Technol. 2001, 35, 2621-2626. [CrossRef]

32. Postma, D.; Larsen, F.; Minh Hue, N.T.; Duc, M.T.; Viet, P.H.; Nhan, P.Q.; Jessen, S. Arsenic in groundwater of the Red River floodplain, Vietnam: Controlling geochemical processes and reactive transport modeling. Geochim. Cosmochim. Acta 2007, 71, 5054-5071. [CrossRef]

33. Polya, D.A.; Berg, M.; Gault, A.G.; Takahashi, Y. Arsenic in Groundwaters of South-East Asia: With Emphasis on Cambodia and Vietnam. Appl. Geochem. 2008, 23, 2968-2976. [CrossRef]

34. Winkel, L.H.E.; Trang, P.T.K.; Lan, V.M.; Stengel, C.; Amini, M.; Ha, N.T.; Viet, P.H.; Berg, M. Arsenic pollution of groundwater in Vietnam exacerbated by deep aquifer exploitation for more than a century. Proc. Natl. Acad. Sci. USA 2011, 108, 1246-1251. [CrossRef]

35. Huy, T.B.; Tuyet-Hanh, T.T.; Johnston, R.; Nguyen-Viet, H. Assessing Health Risk due to Exposure to Arsenic in Drinking Water in Hanam Province, Vietnam. Int. J. Environ. Res. Public Health 2014, 11, 7575-7591. [CrossRef] [PubMed]

36. Hug, S.J.; Leupin, O.X.; Berg, M. Bangladesh and Vietnam: Different groundwater compositions require different approaches to arsenic mitigation. Environ. Sci. Technol. 2008, 42, 6318-6323. [CrossRef] [PubMed]

37. Larsen, F.; Pham, N.Q.; Dang, N.D.; Postma, D.; Jessen, S.; Pham, V.H.; Nguyen, T.B.; Trieu, H.D.; Tran, L.T.; Nguyen, H.; et al. Controlling geological and hydrogeological processes in an arsenic contaminated aquifer on the Red River flood plain, Vietnam. Appl. Geochem. 2008, 23, 3099-3115. [CrossRef]

38. Postma, D.; Larsen, F.; Thai, N.T.; Trang, P.T.K.; Jakobsen, R.; Nhan, P.Q.; Long, T.V.; Viet, P.H.; Murray, A.S. Groundwaer arsenic concentrations in Vietnam controlled by sediment age. Nat. Geosci. 2012, 5, 656-661. [CrossRef]

39. Agusa, T.; Trang, P.T.M.; Lan, V.M.; Anh, D.H.; Tanabe, S.; Viet, P.H.; Berg, M. Human exposure to arsenic from drinking water in Vietnam. Sci. Total Environ. 2014, 488-489, 562-569. [CrossRef]

40. Berg, M.; Trang, P.T.K.; Stengel, C.; Buschmann, J.; Viet, P.H.; Van Dan, N.; Giger, W.; Stüben, D. Hydrological and sedimentary controls leading to arsenic contamination of groundwater in the Hanoi area, Vietnam: The impact of iron-arsenic ratios, peat, river bank deposits, and excessive groundwater abstraction. Chem. Geol. 2008, 249, 91-112. [CrossRef]

41. Postma, D.; Trang, P.T.K.; Sø, H.U.; Hoan, H.V.; Lan, V.M.; Thai, N.T.; Larsen, F.; Viet, P.H.; Jakobsen, R. A model for the evolution in water chemistry of an arsenic contaminated aquifer over the last 6000 years, Red River floodplain, Vietnam. Geochem. Cosmochim. Acta 2016, 195, 277-292. [CrossRef]

42. Nickson, R.T.; McArthur, J.M.; Shrestha, B.; Kyaw-Myint, T.O.; Lowry, D. Arsenic and other drinking water quality issues, Muzaffargarh District, Pakistan. Appl. Geochem. 2005, 20, 55-68. [CrossRef]

43. Ali, W.; Aslam, M.W.; Feng, C.; Junaid, M.; Ali, K.; Li, S.; Chen, Z.; Yu, Z.; Rasool, A.; Zhang, H. Unraveling prevalence and public health risks of arsenic, uranium and co-occurring trace metals in 
groundwater along riverine ecosystem in Sindh and Punjab, Pakistan. Environ. Geochem. Health 2019, 2019, 2223-2238. [CrossRef]

44. Podgorski, J.E.; Equani, S.A.M.A.S.E.; Khanam, T.; Ullah, R.; Shen, H.; Berg, M. Extensive arsenic contamination in high-pH unconfined aquifers in the Indus Valley. Sci. Adv. 2017, 3, e1700935. [CrossRef] [PubMed]

45. Shahid, M.; Niazi, N.K.; Dumat, C.; Naidu, R.; Khalid, S.; Rahman, M.M.; Bibi, I. A meta-analysis of the distribution, sources and health risks of arsenic-contaminated groundwater in Pakistan. Environ. Pollut. 2018, 242, 307-319. [CrossRef] [PubMed]

46. Van Geen, A.; Win, K.H.; Zaw, T.; Naing, W.; Mey, J.I.; Mallioux, B. Confirmation of elevated arsenic levels in groundwater of Myanmar. Sci. Total Environ. 2014, 478, 21-24. [CrossRef] [PubMed]

47. Bacquart, T.; Frisbie, S.; Mitchell, E.; Grigg, L.; Cole, C.; Small, C.; Sarkar, B. Multiple inorganic toxic substances contaminating the groundwater of Myingyan Township, Myanmar: Arsenic, manganese, fluoride, iron, and uranium. Sci. Total Environ. 2015, 517, 232-245. [CrossRef]

48. Richards, L.A.; Pincetti Zúñiga, G.P.; Polya, D.A. Groundwater Arsenic Distribution Reconnaissance Survey in Myanmar. In As2018: The 7th International Congress \& Exhibition on Arsenic in the Environment; Arsenic in a Changing World: Beijing, China, 2018.

49. Pincetti Zúñiga, G.P.; Richards, L.A.; Tun, Y.M.; Aung, H.P.; Swar, A.K.; Reh, U.P.; Khaing, T.; Hlaing, M.M.; Myint, T.A.; Nwe, M.L.; et al. Major and Trace (Including Arsenic) Groundwater Chemistry in Central and Southern Myanmar. Appl. Geochem. 2020, in press. [CrossRef]

50. Das, D.; Samanta, G.; Mandal, B.K.; Chowdhury, T.R.; Chanda, C.R.; Chowdhury, P.P.; Basu, G.K.; Chakraborty, D. Arsenic in groundwater in six districts of West Bengal. Environ. Geochem. Health 1996, 18, 5-15. [CrossRef]

51. Mazumder, D.N.G.; Haque, R.; Ghosh, N.; De, B.K.; Santra, A.; Chakraborty, D.; Smith, A.H. Arsenic levels in drinking water and the prevalence of skin lesions in West Bengal, India. Int. J. Epidemiol. 1998, 27, 871-877. [CrossRef]

52. Hery, M.; van Dongen, B.E.; Gill, F.; Mondal, D.; Vaughan, D.J.; Pancost, R.D.; Polya, D.A.; Lloyd, J.R. Arsenic release and attenuation in low organic carbon aquifer sediments from West Bengal. Geobiology 2010, 8, 155-168. [CrossRef]

53. Chakraborty, A.K.; Saha, K.C. Arsenical dermatosis from tubewell water in West Bengal, India. Indian J. Med. Res. 1987, 85, 326-334.

54. Rowland, H.A.L.; Polya, D.A.; Lloyd, J.R.; Pancost, R.D. Characterisation of organic matter in a shallow, reducing, arsenic-rich aquifer, West Bengal. Org. Geochem. 2006, 37, 1101-1114. [CrossRef]

55. Charlet, L.; Chakraborty, S.; Appelo, C.A.J.; Roman-Ross, G.; Nath, B.; Ansari, A.A.; Lanson, M.; Chatterjee, D.; Mallik, S.B. Chemodynamics of an arsenic "hotspot" in a West Bengal aquifer: A field and reactive transport modeling study. Appl. Geochem. 2007, 22, 1273-1292. [CrossRef]

56. Mazumder, D.N.G.; Chakraborti, A.K.; Ghose, A.; Gupta, J.D.; Chakraborty, D.P.; Dey, S.B.; Chattopadhyay, N. Chronic arsenic toxicity from drinking tubewell water in rural West Bengal. Bull. World Health Organ. 1988, 66, 499-506.

57. Sengupta, S.; McArthur, J.; Sarkar, A.; Leng, M.J.; Ravenscroft, P.; Howarth, R.J.; Banerjee, D.M. Do Ponds Cause Arsenic-Pollution of Groundwater in the Bengal Basin? An Answer from West Bengal. Environ. Sci. Technol. 2008, 42, 5156-5164. [CrossRef] [PubMed]

58. Lawson, M.; Ballentine, C.J.; Polya, D.A.; Boyce, A.J.; Mondal, D.; Chatterjee, D.; Majumder, S.; Biswas, A. The geochemical and isotopic composition of ground waters in West Bengal: Tracing ground-surface water interaction and its role in arsenic release. Mineral. Mag. 2008, 72, 441-444. [CrossRef]

59. Chowdhury, U.K.; Biswas, B.K.; Chowdhury, T.R.; Samanta, G.; Mandal, B.K.; Basu, G.C.; Chanda, C.R.; Lodh, D.; Saha, K.C.; Mukherjee, S.K.; et al. Groundwater arsenic contamination in Bangladesh and West Bengal, India. Environ. Health Perspect. 2000, 108, 393-397. [CrossRef] [PubMed]

60. Nickson, R.T.; McArthur, J.M.; Ravenscroft, P.; Burgess, W.G.; Ahmed, K.M. Mechanism of arsenic release to groundwater, Bangladesh and West Bengal. Appl. Geochem. 2000, 15, 403-413. [CrossRef]

61. Gault, A.G.; Islam, F.S.; Polya, D.A.; Charnock, J.M.; Boothman, C.; Chatterjee, D.; Lloyd, J.R. Microcosm depth profiles of arsenic release in a shallow aquifer, West Bengal. Mineral. Mag. 2005, 69, 855-863. [CrossRef] 
62. McArthur, J.M.; Banerjee, D.M.; Sengupta, S.; Ravenscroft, P.; Klump, S.; Sarkar, A.; Disch, B.; Kipfer, R. Migration of As, and ${ }^{3} \mathrm{H} /{ }^{3} \mathrm{He}$ ages, in groundwater from West Bengal: Implications for monitoring. Water Res. 2010, 44, 4171-4185. [CrossRef]

63. Pal, T.; Mukherjee, P.K.; Sengupta, S. Nature of arsenic pollutants in groundwater of Bengal basin-A case study for Baruipur area, West Bengal, India. Curr. Sci. 2002, 82, 554-561.

64. Charlet, L.; Chakraborty, S.; Appello, T.; Latscha, A.A.; Chatterjee, D.; Mallick, B. Propogation of natural arsenic plume in West Bengal, India. J. Phys. IV 2003, 107, 285-288.

65. Mukherjee, A.; Fryar, A.E.; Howell, P.D. Regional hydrostratigraphy and groundwater flow modeling in the arsenic-affecte areas of the western Bengal basin, West Bengal, India. Hydrogeol. J. 2007. [CrossRef]

66. Mukherjee, A.; Fryar, A.E. Deeper groundwater chemistry and geochemical modeling of the arsenic affected western Bengal basin, West Bengal, India. Appl. Geochem. 2008, 23, 863-894. [CrossRef]

67. Bhowmick, S.; Pramanik, S.; Singh, P.; Mondal, P.; Chatterjee, D.; Nriagu, J. Arsenic in groundwater of West Bengal, India: A review of human health risks and assessment of possible intervention options. Sci. Total Environ. 2018, 612, 148-169. [CrossRef] [PubMed]

68. Bhattacharyya, R.; Chatterjee, D.; Nath, B.; Jana, J.; Jacks, G.; Vahter, M. High arsenic groundwater: Mobilization, metabolism and mitigation-An overview in the Bengal Delta Plain. Mol. Cell. Biochem. 2003, 253, 347-355. [CrossRef] [PubMed]

69. McArthur, J.M.; Ghosal, U.; Sikdar, P.K.; Ball, J.D. Arsenic in Groundwater: The Deep Late Pleistocene Aquifers of the Western Bengal Basin. Environ. Sci. Technol. 2016, 50, 3469-3476. [CrossRef] [PubMed]

70. McArthur, J.M.; Sikdar, P.K.; Nath, B.; Grassineau, N.; Marshall, J.D.; Banerjee, D.M. Sedimentological Control on Mn, and Other Trace Elements, In Groundwater of the Bengal Delta. Environ. Sci. Technol. 2012, 46, 669-676. [CrossRef]

71. McArthur, J.M.; Sikdar, P.K.; Leng, M.J.; Ghosal, U.; Sen, I. Groundwater Quality beneath an Asian Megacity on a Delta: Kolkata's (Calcutta's) Disappearing Arsenic and Present Manganese. Environ. Sci. Technol. 2018, 52, 5161-5172. [CrossRef]

72. Kumar, M.; Kumar, P.; Ramanathan, A.L.; Bhattacharya, P.; Thunvik, R.; Singh, U.K.; Tsujimura, M.; Sracek, O. Arsenic enrichment in groundwater in the middle Gangetic Plain of Ghazipur District in Uttar Pradesh, India. J. Geochem. Explor. 2010, 105, 83-94. [CrossRef]

73. Ahamed, S.; Sengupta, M.K.; Mukherjee, A.; Hossain, M.A.; Das, B.; Nayak, B.; Pal, A.; Mukherjee, S.C.; Pati, S.; Dutta, R.N.; et al. Arsenic groundwater contamination and its health effects in the state of Uttar Pradesh (UP) in upper and middle Ganga plain, India: A severe danger. Sci. Total Environ. 2006, 370, 310-322. [CrossRef]

74. Srivastava, S.; Sharma, Y.K. Arsenic occurrence and accumulation in soil and water of eastern districts of Uttar Pradesh, India. Environ. Monit. Assess. 2013, 185, 4995-5002. [CrossRef]

75. Chauhan, V.S.; Nickson, R.T.; Chauhan, D.; Iyengar, L.; Sankararamakrishnan, N. Ground water geochemistry of Ballia district, Uttar Pradesh, India and mechanism of arsenic release. Chemosphere 2009, 75, 83-91. [CrossRef] [PubMed]

76. Chakraborti, D.; Mukherjee, S.; Pati, S.; Sengupta, M.K.; Rahman, M.; Chowdhury, M.; Lodh, D.; Chanda, C.R.; Chakraborti, A.K.; Basu, G.K. Arsenic Groundwter Contamination in Middle Ganga Plain, Bihar, India: A Future Danger? Environ. Health Perspect. 2003, 111, 1194-1201. [CrossRef]

77. Nickson, R.; Sengupta, C.; Mitra, P.; Dave, S.N.; Banerjee, A.K.; Bhattacharya, A.; Basu, S.; Kakoti, N.; Moorthy, N.S.; Wasuja, M.; et al. Current knowledge on the distribution of arsenic in groundwater in five states of India. J. Environ. Sci. Health Part A 2007, 42, 1707-1718. [CrossRef]

78. Chakraborti, D.; Singh, S.K.; Rahman, M.M.; Dutta, R.N.; Mukherjee, S.C.; Pati, S.; Kar, P.B. Groundwater Arsenic Contamination in the Ganga River Basin: A Future Health Danger. Int. J. Environ. Res. Public Health 2018, 15, 180. [CrossRef] [PubMed]

79. Saha, D.; Sarangam, S.S.; Dwivedi, S.N.; Bhartariya, K.G. Evaluation of hydrogeochemical processes in arsenic-contaminated alluvial aquifers in parts of Mid-Ganga Basin, Bihar, Eastern India. Environ. Earth Sci. 2010, 61, 799-811. [CrossRef]

80. Ghosh, A.K.; Bose, N.; Kumar, R.; Bruining, H.; Lourma, S.; Donselaar, M.E.; Bhatt, A.G. Geological origin of arsenic groundwater contamination in Bihar, India. In Understanding the Geological and Medical Interface of Arsenic; Ng, J.C., Noller, B.N., Naidu, R., Bundschuh, J., Bhattacharya, P., Eds.; Taylor \& Francis Group: London, UK, 2012. 
81. Saha, D.; Sahu, S.; Chandra, P.C. Arsenic-safe alternate aquifers and their hydraulic characteristics in contaminated areas of Middle Ganga Plain, Eastern India. Environ. Monit. Assess. 2011, 175, 331-348. [CrossRef]

82. Saha, D. Arsenic goundwater contamination in parts of middle Ganga plain, Bihar. Curr. Sci. 2009, 97, 753-755.

83. Ghosh, A.K.; Singh, S.K.; Singh, S.; Singh, A.; Roy, N.P.; Upadhyaya, A.; Bose, N.; Chaudhary, S.; Mishra, R. Study of Arsenic Contamination in Ground Water of Bihar, (India) Along the River Ganges. In Proceedings of the 3rd International Conference on Water Quality Management, Nagpur, India, 6-8 February 2008.

84. Suman, S.; Sharma, P.; Siddique, A.B.; Rahman, M.A.; Kumar, R.; Rahman, M.M.; Bose, N.; Singh, S.K.; Ghosh, A.K.; Matthews, H.; et al. Wheat is an emerging exposure route for arsenic in Bihar, India. Sci. Total Environ. 2020, 703, 134774. [CrossRef]

85. Chakraborti, D.; Rahman, M.M.; Bas, B.; Chatterjee, A.; Das, D.; Nayak, B.; Pal, A.; Chowdhury, U.K.; Ahmed, S.; Biswas, B.K.; et al. Groundwater arsenic contamination and its health effects in India. Hydrogeol. J. 2017, 25, 1165-1181. [CrossRef]

86. Brugge, D.; Buchner, V. Health effects of uranium: New research findings. Rev. Environ. Health 2011, 26, 231-249. [CrossRef]

87. Kurttio, P.; Auvinen, A.; Salonen, L.; Saha, H.; Pekkanen, J.; Mäkeläinen, I.; Väisänen, I.S.B.; Penttilä, M.; Komulainen, H. Renal effects of uranium in drinking water. Environ. Health Perspect. 2002, 10, 337-342. [CrossRef] [PubMed]

88. Banning, A.; Demmel, T.; Rüde, T.R.; Wrobel, M. Groundwater Uranium Origin and Fate Control in a River Valley Aquifer. Environ. Sci. Technol. 2013, 47, 13941-13948. [CrossRef] [PubMed]

89. Alam, M.S.; Cheng, T. Uranium release from sediment to groundwater: Influence of water chemistry and insights into release mechanisms. J. Contam. Hydrol. 2014, 164, 72-87. [CrossRef] [PubMed]

90. Yang, Q.; Smitherman, P.; Hess, C.T.; Culbertson, C.W.; Marvinney, R.G.; Smith, A.E.; Zheng, Y. Uranium and Radon in Private Bedrock Well Water in Maine: Geospatial Analysis at Two Scales. Environ. Sci. Technol. 2014, 48, 4298-4306. [CrossRef]

91. Welch, A.H.; Lico, M.S. Factors controlling As and U in shallow ground water, southern Carson Desert, Nevada. Appl. Geochem. 1998, 13, 521-539. [CrossRef]

92. Seldén, A.I.; Lundholm, C.; Edlund, B.; Högdahl, C.; Ek, B.-M.; Bergström, B.E.; Ohlson, C.-G. Nephrotoxity of uranium in drinking water from private drilled wells. Environ. Res. 2009, 109, 486-494. [CrossRef]

93. Stalder, E.; Blanc, A.; Haldimann, M.; Dudler, V. Occurrence of uranium in Swiss drinking water. Chemosphere 2012, 86, 672-679. [CrossRef]

94. Smedley, P.L.; Smith, B.; Abesser, C.; Lapworth, D. Uranium Occurrence and Behaviour in British Groundwater (Groundwater Systems \& Water Quality Programme Commissioned Report CR/06/050N); British Geological Survey: Nicker Hill, UK, 2006.

95. Frisbie, S.H.; Mitchell, E.J.; Mastera, L.J.; Maynard, D.M.; Yusuf, A.Z.; Siddiq, M.Y.; Ortega, R.; Dunn, R.K.; Westerman, D.S.; Bacquart, T.; et al. Public Health Strategies for Western Bangladesh That Address Arsenic, Manganese, Uranium, and Other Toxic Elements in Drinking Water. Environ. Health Perspect. 2009, 117, 410-416. [CrossRef]

96. Guo, H.; Jia, Y.; Wanty, R.B.; Jiang, Y.; Zhao, W.; Xiu, W.; Shen, J.; Li, Y.; Cao, Y.; Wu, Y.; et al. Contrasting distributions of groundwater arsenic and uranium in the western Hetao basin, Inner Mongolia: Implications for origins and fate controls. Sci. Total Environ. 2016, 541, 1172-1190. [CrossRef]

97. Wu, Y.; Wang, Y.; Xie, X. Occurrence, behavior and distribution of high levels of uranium in shallow groundwater at Datong basin, northern China. Sci. Total Environ. 2014, 472, 809-817. [CrossRef]

98. Moon, S.H.; Hwang, J.; Lee, J.Y.; Hyun, S.P.; Bae, B.K.; Park, Y. Establishing the Origin of Elevated Uranium Concnetrations in Groundwater near the Central Ogcheon Metamorphic Belt, Korea. J. Environ. Qual. 2013, 42, 118-128. [CrossRef] [PubMed]

99. Nriagu, J.; Nam, D.-H.; Ayanwola, T.A.; Dinh, H.; Erdenechimeg, E.; Ochir, C.; Bolormaa, T.-A. High levels of uranium in groundwater of Ulaanbaatar, Mongolia. Sci. Total Environ. 2012, 414, 722-726. [CrossRef] [PubMed]

100. Buschmann, J.; Berg, M.; Stengel, C.; Winkel, L.; Sampson, M.L.; Trang, P.T.K.; Viet, P.H. Contamination of drinking water resources in the Mekong delta floodplains: Arsenic and other trace metals pose serious health risks to population. Environ. Int. 2008, 34, 756-764. [CrossRef] [PubMed] 
101. Bhangare, R.C.; Tiwari, M.; Ajmal, P.Y.; Sahu, S.K.; Pandit, G.G. Laser fluorimetric analysis of uranium in water from Vishakhapatnam and estimation of health risk. Radiat. Prot. Environ. 2013, 36, 128-132.

102. Kumar, D.; Singh, A.; Jha, R.K.; Sahoo, S.K.; Jha, V. Using spatial statistics to identify the uranium hotspot in groundwater in the mid-eastern Gangetic plain, India. Environ. Earth Sci. 2018, 77, 702. [CrossRef]

103. Kumar, D.; Singh, A.; Jha, R.K. Spatial distribution of uranium and basic water quality parameter in the capital of Bihar and consequent ingestion dose. Environ. Sci. Pollut. Res. 2018, 25, 17901-17914. [CrossRef]

104. Kumar, D.; Singh, A.; Kumar, P.; Jha, R.K.; Sahoo, S.K.; Jha, V. Sobol sensitivity analysis for risk assessment of uranium in groundwater. Environ. Geochem. Health 2020. [CrossRef]

105. Sar, S.K.; Diwan, V.; Biswas, S.; Singh, S.; Sahu, M.; Jindal, M.K.; Arora, A. Study of uranium level in groundwater of Balod district of Chhattisgarh state, India and assessment of health risk. Hum. Ecol. Risk Assess. 2018, 24, 691-698. [CrossRef]

106. Singh, B.; Garg, V.K.; Yadav, P.; Kishor, N.; Pulhani, V. Uranium in groundwater from Western Haryana, India. J. Radioanal. Nucl. Chem. 2014, 301, 427-433. [CrossRef]

107. Ajay, K.; Manpreet, K.; Rohit, M.; Sumit, S.; Rosaline, M.; Singh, K.P.; Bajwa, B.S. Quantification and assessment of health risk due to ingestion of uranium in groundwater of Jammu district, Jammu \& Kashmir, India. J. Radioanal. Nucl. Chem. 2016, 310, 793-804.

108. Patra, A.C.; Mohapatra, S.; Sahoo, S.K.; Lenka, P.; Dubey, J.S.; Tripathi, R.M.; Puranik, V.D. Age-Dependent Dose and Health Risk due to Intake of Uranium in Drinking Water from Jaduguda, India. Radiat. Prot. Dosim. 2013, 155, 210-216. [CrossRef] [PubMed]

109. Sethy, N.K.; Tripathi, R.M.; Jha, V.N.; Sahoo, S.K.; Shukla, A.K.; Puranik, V.D. Assessment of Natural Uranium in the Groundwater around Jaduguda Uranium Mining Complex, India. J. Environ. Prot. 2011, 2, 1002-1007. [CrossRef]

110. Gupta, S.; Saravanan, B.; Agarwal, M.; Yadav, G.S.; Kumar, P. Hydrogeochemical Constraints of Uranium Solubility and Groundwater Quality in Aquifers of Central and Western Parts of Singhbhum Shear Zone, Jharkhand, India. J. Groundw. Res. 2016, 5, 16-36.

111. Singh, S.; Malhotra, R.; Kumar, J.; Singh, B.; SIngh, L. Uranium analysis of geological samples, water and plants from Kulu Area, Himachal Pradesh, India. Radiat. Meas. 2001, 34, 427-431. [CrossRef]

112. Nagaiah, N.; Mathews, G.; Balakrishna, K.K.M.; Rajanna, A.M.; Naregundi, K. Influence of physico-chemical parameters on the distribution of uranium in the ground water of Bangalore, India. Radiat. Prot. Environ. 2013, 36, 175-180. [CrossRef]

113. Ben Byju, B.; Sunil, A.; Reba, M.J.; Christa, E.P.; Vaidyan, V.K.; Prasad, R.; Jojo, P.J. Uranium in drinking water from the south coast districts of Kerala, India. Int. J. Radiat. Res. 2012, 10, 31-36.

114. Kumar, A.; Usha, N.; Sawant, P.D.; Tripathi, R.M.; Raj, S.S.; Mishra, M.; Rout, S.; Supreeta, P.; Singh, J.; Kumar, S.; et al. Risk Assessment for Natural Uranium in Subsurface Water of Punjab State, India. Hum. Ecol. Risk Assess. 2011, 17, 381-393. [CrossRef]

115. Rani, A.; Mehra, R.; Duggal, V.; Balaram, V. Analysis of Uranium Concentration in Drinking Water Samples Using ICPMS. Health Phys. 2013, 104, 251-255. [CrossRef]

116. Kumar, M.P.; Prerna, S.; Akash, K.; Prasad, M.K. Uranium in Ground water of Eastern Uttar Pradesh, India: A prelimary study. Int. Res. J. Env. Sci. 2015, 4, 70-74.

117. Yadav, S.K.; Ramanathan, A.L.; Kumar, M.; Chidambaram, S.; Sautam, Y.P.; Tiwari, C. Assessment of arsenic and uranium co-occurrences in groundwater of central Gangetic Plain, Uttar Pradesh, India. Environ. Earth Sci. 2020, 79, 154. [CrossRef]

118. Islam, F.S.; Gault, A.G.; Boothman, C.; Polya, D.A.; Charnock, J.M.; Chatterjee, D.; Lloyd, J.R. Role of metal-reducing bacteria in arsenic release from Bengal delta sediments. Nature 2004, 430, 68-71. [CrossRef]

119. Bhattacharya, P.; Chatterjee, D.; Jacks, G. Occurence of arsenic contaminated groundwater in alluvial aquifers from delta plains, Eastern India: Options for safe drinking water supply. Water Resour. Dev. 1997, 13, 79-92. [CrossRef]

120. Van Geen, A.; Rose, J.; Thoral, S.; Garnier, J.M.; Zheng, Y.; Bottero, J.Y. Decoupling of As and Fe release to Bangladesh groundwater under reducing conditions. Part II: Evidence from sediment incubations. Geochim. Cosmochim. Acta 2004, 68, 3475-3486. [CrossRef] 
121. Rowland, H.A.L.; Boothman, C.; Pancost, R.D.; Gault, A.G.; Polya, D.A.; Lloyd, J.R. The role of indigenous mircoorganisms in the biodegradation of naturally occurring petroleum, the reduction of iron, and the mobilization of arsenite from West Bengal aquifer sediments. J. Environ. Qual. 2009, 38, 1598-1607. [CrossRef] [PubMed]

122. McArthur, J.M.; Banerjee, D.M.; Hudson-Edwards, K.A.; Mishra, R.; Purohit, R.; Ravenscroft, P.; Cronin, A.; Howarth, R.J.; Chatterjee, A.; Talukder, T.; et al. Natural organic matter in sedimentary basins and its relation to arsenic in anoxic ground water: The example of West Bengal and its worldwide implications. Appl. Geochem. 2004, 19, 1255-1293. [CrossRef]

123. Rowland, H.A.L.; Pederick, R.L.; Polya, D.A.; Pancost, R.D.; van Dongen, B.E.; Gault, A.G.; Vaughan, D.J.; Bryant, C.; Anderson, B.; Lloyd, J.R. The control of organic matter on microbially mediated iron reduction and arsenic release in shallow alluvial aquifers, Cambodia. Geobiology 2007, 5, 281-292. [CrossRef]

124. Neumann, R.B.; Polizzotto, M.L.; Badruzzaman, A.B.M.; Ali, M.A.; Zhang, Z.Y.; Harvey, C.F. Hydrology of a groundwater-irrigated rice field in Bangladesh: Seasonal and daily mechanisms of infiltration. Water Resour. Res. 2009, 45, 14. [CrossRef]

125. Fendorf, S.; Michael, H.A.; Van Geen, A. Spatial and temporal variations of groundwater arsenic in south and southeast Asia. Science 2010, 328, 1123-1127. [CrossRef]

126. Mladenov, N.; Zheng, Y.; Miller, M.P.; Nemergut, D.R.; Legg, T.; Simone, B.; Hageman, C.; Rahman, M.M.; Ahmed, K.M.; McKnight, D.M. Dissolved Organic Matter Sources and Consequences for Iron and Arsenic Mobilization in Bangladesh Aquifers. Environ. Sci. Technol. 2010, 44, 123-128. [CrossRef]

127. Al Lawati, W.M.; Rizoulis, A.; Eiche, E.; Boothman, C.; Polya, D.A.; Lloyd, J.R.; Berg, M.; Vasquez-Aguilar, P.; van Dongen, B.E. Characterisation of organic matter and microbial communities in contrasting arsenic-rich Holocene and arsenic-poor Pleistocene aquifers, Red River Delta, Vietnam. Appl. Geochem. 2012, 27, 315-325. [CrossRef]

128. Al Lawati, W.M.; Jean, J.-S.; Kulp, T.R.; Lee, M.-K.; Polya, D.A.; Liu, C.-C.; van Dongen, B.E. Characterisation of organic matter associated with groundwater arsenic in reducing aquifers of southwestern Taiwan. J. Hazard. Mater. 2013, 262, 970-979. [CrossRef] [PubMed]

129. Neumann, R.B.; Pracht, L.E.; Polizzotto, M.L.; Badruzzaman, A.B.M.; Ashraf Ali, M. Biodegradable Organic Carbon in Sediments of an Arsenic-Contaminated Aquifer in Bangladesh. Environ. Sci. Technol. Lett. 2014, 1, 221-225. [CrossRef]

130. McArthur, J.M.; Ravenscroft, P.; Sracek, O. Aquifer arsenic source. Nat. Geosci. 2011, 4, 655-656. [CrossRef]

131. Neumann, R.B.; Ashfaque, K.N.; Badruzzaman, A.B.M.; Ali, M.A.; Shoemaker, J.K.; Harvey, C.F. Aquifer arsenic source reply. Nat. Geosci. 2011, 4, 656. [CrossRef]

132. Datta, S.; Neal, A.W.; Mohajerin, T.J.; Ocheltree, T.; Rosenheim, B.E.; White, C.D.; Johannesson, K.H. Perennial ponds are not an important source of water or dissolved organic matter to groundwaters with high arsenic concentrations in West Bengal, India. Geophys. Res. Lett. 2011, 38, L20404. [CrossRef]

133. Schaefer, M.V.; Ying, S.C.; Benner, S.G.; Duan, Y.; Wang, Y.; Fendorf, S. Aquifer Arsenic Cycling Induced by Seasonal Hydrologic Changes within the Yangtze River Basin. Environ. Sci. Technol. 2016, 50, 3521-3529. [CrossRef]

134. Stuckey, J.W.; Schaefer, M.V.; Kocar, B.D.; Benner, S.G.; Fendorf, S. Arsenic release metabolically limited to permanently water-saturated soil in Mekong Delta. Nat. Geosci. 2016, 9, 70-76. [CrossRef]

135. Goldberg, S.; Criscenti, L.J.; Turner, D.R.; Davis, J.A.; Cantrell, K.J. Adsorption-Desorption Processes in Subsurface Reactive Transport Modelling. Vadose Zone J. 2007, 6, 407-435. [CrossRef]

136. Richards, L.A.; Casanueva-Marenco, M.J.; Magnone, D.; Sovann, C.; van Dongen, B.E.; Polya, D.A. Contrasting Sorption Behaviours Affected Groundwater Arsenic Concentration in Kandal Province, Cambodia. Geosci. Front. 2019, 10, 1701-1713. [CrossRef]

137. Lalonde, K.; Mucci, A.; Ouellet, A.; Gélinas, Y. Preservation of organic matter in sediments promoted by iron. Nature 2012, 483, 198-200. [CrossRef]

138. Johnson, K.; Purvis, G.; Lopez-Capel, E.; Peacock, C.; Gray, N.; Wagner, T.; März, C.; Bowen, L.; Ojeda, J.; Finlay, N.; et al. Towards a mechanistic understanding of carbon stabilization in manganese oxides. Nat. Commun. 2015, 6, 7628. [CrossRef] [PubMed]

139. Spycher, N.F.; Issarangun, M.; Stewart, B.D.; Şengör, S.; Belding, E.; Ginn, T.R.; Peyton, B.M.; Sani, R.K. Biogenic uraninite precipitation and its reoxidation by iron(III) (hydr)oxides: A reaction modelling approach. Geochem. Cosmochim. Acta 2011, 75, 4426-4440. [CrossRef] 
140. Langmuir, D. Uranium solution-mineral equilibria at low temperatures with applications to sedimentary ore deposits. Geochem. Cosmochim. Acta 1978, 42, 547-569. [CrossRef]

141. Katsoyiannis, I.; Hug, S.J.; Ammann, A.; Zikoudi, A.; Hatziliontos, C. Arsenic speciation and uranium concentrations in drinking water supply wells in Northern Greece: Correlations with redox indicative parameters and implications for groundwater treatment. Sci. Total Environ. 2007, 383, 128-140. [CrossRef]

142. Dong, W.; Brooks, S.C. Determination of the Formation Constants of Ternary Complexes of Uranyl and Carbonate with Alkaline Earth Metals $\left(\mathrm{Mg}^{2+}, \mathrm{Ca}^{2+}, \mathrm{Sr}^{2+}\right.$, and $\left.\mathrm{Ba}^{2+}\right)$ Using Anion Exchange Method. Environ. Sci. Technol. 2006, 40, 4689-4695. [CrossRef]

143. Artinger, R.; Rabung, T.; Kim, J.I.; Sachs, S.; Schmeide, K.; Heise, K.H.; Bernhard, G.; Nitsche, H. Humic colloid-borne migration of uranium in sand columns. J. Contam. Hydrol. 2002, 58, 1-12. [CrossRef]

144. Regenspurg, S.; Margot-Roquier, C.; Harfouche, M.; Froidevaux, P.; Steinmann, P.; Junier, P.; Bernier-Latmani, R. Speciation of naturally-accumulated uranium in an organic-rich soil of an alpine region (Switzerland). Geochem. Cosmochim. Acta 2010, 74, 2082-2098. [CrossRef]

145. Richards, L.A.; Kumar, A.; Shankar, P.; Gaurav, A.; Ghosh, A.; Polya, D.A. Distribution of Arsenic and Uranium in Groundwater Utilized as Drinking Water in Bihar, India. In Proceedings of the Abstract of the As2020 8th International Congress \& Exhibition of Arsenic in the Environment, Wageningen, The Netherlands. Originally scheduled for 15-18 June 2020; postponed Due to COVID-19.

146. Natural Earth. Natural Earth Data. Available online: https://www.naturalearthdata.com/ (accessed on 1 April 2020).

147. United States Department of Interior. Geologic map of South Asia (geo8ag). Available online: https: //catalog.data.gov/dataset/geologic-map-of-south-asia-geo8ag-48972 (accessed on 1 April 2020).

148. Polya, D.A.; Watts, M.J. Chapter 5: Sampling and analysis for monitoring arsenic in drinking water. In Best Practice Guide on the Control of Arsenic in Drinking Water; Bhattacharya, P., Polya, D.A., Jovanovic, D., Eds.; IWA Publishing: London, UK, 2017; ISBN 9781843393856.

149. Polya, D.A.; Richards, L.A.; Al Bualy, A.N.; Sovann, C.; Magnone, D.; Lythgoe, P.R. Chapter A14: Groundwater sampling, arsenic analysis and risk communication: Cambodia Case Study. In Best Practice Guide for the Control of Arsenic in Drinking Water; Bhattacharya, P., Polya, D.A., Jovanovic, D., Eds.; IWA Publishing: London, UK, 2017; ISBN 9781843393856.

150. Frisbie, S.H.; Mitchell, E.J.; Dustin, H.; Maynard, D.M.; Sarkar, B. World Health Organization discontinues its drinking-water guideline for manganese. Environ. Health Perspect. 2012, 120, 775-778. [CrossRef]

151. Wasserman, G.A.; Lui, X.; Parvez, F.; Ahsan, H.; Levy, D.; Factor-Litvak, P.; Kline, J.; van Geen, A.; Slavkovich, V.; Lolacono, N.J.; et al. Water Manganese Exposure and Children's Intellectual Function in Araihazar, Bangladesh. Environ. Health Perspect. 2005, 114, 124-129. [CrossRef]

152. Singh, A.K.; Sengupta, D.; Prasad, R. Radon exhalation rate and uranium estimation in rock samples from Bihar uranium and copper mines using the SSNTD technique. Appl. Radiat. Isot. 1999, 51, 107-113. [CrossRef]

153. Xie, X.; Wang, Y.; Su, C. Hydrochemical and Sediment Biomarker Evidence of the Impact of Organic Matter Biodegradation on Arsenic Mobilization in Shallow Aquifers of Datong Basin, China. Water Air Soil Pollut. 2012, 223, 483-498. [CrossRef]

(C) 2020 by the authors. Licensee MDPI, Basel, Switzerland. This article is an open access article distributed under the terms and conditions of the Creative Commons Attribution (CC BY) license (http://creativecommons.org/licenses/by/4.0/). 